\title{
Structural Characteristics of Patches in the Central Lika Landscape - Application of Spatial and Regression Analysis
}

\author{
Marta HAMZIĆ ${ }^{1}$, Borna FUERST-BJELIŠ2, Mladen PAHERNIK³
}

1 Ericsson Nikola Tesla d.d., Krapinska 45, Zagreb

marta.jovanic@gmail.com

2 Sveučilište u Zagrebu, Prirodoslovno-matematički fakultet, Geografski odsjek, Marulićev trg 19, Zagreb

bornafb@geog.pmf.unizg.hr

${ }^{3}$ Centar za obrambene i strateške studije „Janko Bobetko“, Hrvatsko vojno učilište „Dr. Franjo Tuđman“, Ilica 256b, Zagreb

mladen.pahernik@morh.hr

Abstract. This paper analyses the structural characteristics (shape, position and condition) of landscape patches in Central Lika according to landscape types and for the landscape of Central Lika as a whole. A set of indicators for the landscape structure was used along with GIS technology. Interrelation of the structural characteristics of landscape patches were determined using regression analysis. When determining the landscape types of Central Lika, a method based on land cover/land use was applied. For this purpose, data from the CORINE database for the year 2012 were used. At the level of the landscape type in Central Lika and the landscape of Central Lika as a whole, a set of indicators for the landscape structure were used, based on a variety of spatial analysis methods: Mean Shape Index - for the landscape patch shapes; Core Area Index - for the condition of the landscape patches, and Average Nearest Neighbour - for the position of the landscape patches. The most important result of this paper was to confirm the correlation between the shape and condition, and between the shape and position of the landscape patches of Central Lika, while no correlation between the condition and position of the landscape patches of Central Lika was found.

Keywords: Land cover/land use, structural characteristics, landscape patches, GIS, regression analysis, spatial analysis, Central Lika

\section{Introduction}

A natural landscape is defined by natural factors: climate, soil, water, relief, geological foundation, and flora and fauna (Herlitzius et al. 2009). Any landscape is continuously exposed to changes caused by natural forces as well as socioeconomic activities. By changing just one of these natural factors through human activity, way of life, or the culture of particular social groups, a natural landscape becomes a cultural landscape. Thus, it can be said that today, most landscapes on Earth are in fact cultural, and the way they develop or change is "an expression of the dynamic interaction of natural and cultural influences" (Antrop 2005:22). The consequences of this interaction are visible in the strong connectivity in the mosaic of landscape patches and ecological processes (Fu et al. 2006), as well as anthropogenic activities. In fact, processes that take place in the landscape create patterns and structures, while being driven and directed by the prevailing spatial structures. In short, these are the reasons and consequences of spatial heterogeneity for various ecological processes (Lang and Blaschke 2010).

The structure of the landscape represents a specific combination of parts, that is, landscape patches.

KiG No. 34, Vol. 19, 2020 https://doi.org/10.32909/kg.19.34.2 - - 


\title{
Strukturna obilježja uzoraka krajolika Srednje Like - primjena prostorne i regresijske analize
}

\author{
Marta HAMZIĆ1, Borna FUERST-BJELIŠ2 ${ }^{2}$ Mladen PAHERNIK³ \\ 1 Ericsson Nikola Tesla d.d., Krapinska 45, Zagreb \\ marta.jovanic@gmail.com \\ 2 Sveučilište u Zagrebu, Prirodoslovno-matematički fakultet, Geografski odsjek, Marulićev trg 19, Zagreb \\ bornafb@geog.pmf.unizg.hr \\ ${ }^{3}$ Centar za obrambene i strateške studije „Janko Bobetko“, Hrvatsko vojno učilište „Dr. Franjo Tuđman“, llica 256b, Zagreb \\ mladen.pahernik@morh.hr
}

\begin{abstract}
Sažetak. U ovom radu analiziraju se strukturna obilježja (oblik, položaj i stanje) uzoraka krajolika Srednje Like za tipove krajolika i krajolik Srednje Like u cjelini. Pri tome se koristi skup pokazatelja za strukturu krajolika i GIS tehnologija. Međuodnos strukturnih obilježja uzoraka krajolika utvrđen je linearno-regresijskom analizom. Pristup utvrđivanju tipova krajolika Srednje Like temelji se na zemljišnom pokrovu/načinu korištenja zemljišta. U tu svrhu korišteni su podatci baze podataka CORINE za 2012. godinu. Na razini tipa krajolika Srednje Like i krajolik Srednje Like u cjelini upotrijebljen je skup pokazatelja za strukturu krajolika koji se temelji na različitim metodama prostorne analize: Mean Shape Index - za oblik uzoraka krajolika; Core Area Index - za stanje uzoraka krajolika; Average Nearest Neighbour - za položaj uzoraka krajolika. Najvažniji je rezultat ovog rada da je regresijskom analizom ustanovljena povezanost za oblik i stanje, te za oblik i položaj uzoraka krajolika Srednje Like, dok nije utvrđena povezanost za stanje i položaj uzoraka krajolika Srednje Like.
\end{abstract}

Ključne riječi: Zemljišni pokrov/način korištenja zemljišta, strukturna obilježja, uzorci krajolika, GIS, linearno-regresijska analiza, prostorna analiza, Srednja Lika

\section{Uvod}

Prirodni se krajolik može definirati prirodnim čimbenicima: klimom, tlom, vodom, reljefom, geološkom osnovom, florom i faunom (Herlitzius i dr. 2009). On je konstantno izložen promjenama uzrokovanim kako prirodnim silama tako i društveno-gospodarskim aktivnostima. Promjenom makar samo jednog od prirodnih čimbenika čovjekovom djelatnošću, načinom života/ kulturom pojedinih društvenih grupa, prirodni krajolik postaje kulturni. Stoga se može reći kako su danas gotovo svi krajolici na Zemlji zapravo kulturni, a razvoj krajolika odnosno njegove promjene su „izraz dinamične interakcije prirodnih i kulturnih utjecaja" (Antrop 2005:22). Posljedice te interakcije vidljive su i u jakoj povezanosti mozaika uzoraka krajolika i ekoloških procesa (Fu i dr. 2006) te antropogenog djelovanja. Naime, procesi koji se odvijaju u krajoliku stvaraju uzorke i strukture, no istodobno ih vode i usmjeruju prostorne strukture koje prevladavaju. Ukratko, riječ je o uzrocima i posljedicama prostornoga heterogeniteta za različite ekološke procese (Lang i Blaschke 2010).

Struktura krajolika je specifičan spoj dijelova, tj. uzoraka krajolika. Obilježja strukture krajolika kao prostorne komponente mogu se jasno promatrati, opisivati i kvantificirati (Blaschke 2000). Razlog tome 
The characteristics of landscape structure as a spatial component are easily observed, described and quantified (Blaschke 2000). This can be done using computational devices, geographical data processing methods, and digital image processing, which have had a great influence on studying the structure or development of landscapes (Lang and Blaschke 2010).

When determining landscape types, two approaches are used: one is based on land cover/land use and the other is based on the synthesis of natural and cultural characteristics using a hierarchical approach (Dumbović Bilušić 2015). As a result of this, and given the observed features, the more homogeneous spatial parts of the landscape can be determined, which are then classified into landscape types.

The objective of this paper, using the appropriate spatial analysis methods, is to determine individual structural characteristics (shape, position and condition) of the landscape patches of Central Lika according to landscape types for the year 2012 and, using regression analysis, to determine the possible correlation between them.

When determining landscape types in Central Lika, an approach based on land cover/land use was applied. Data from the CORINE Land Cover database for 2012 (CLC 2012) were used. The data point to the natural geographical characteristics and socio-geographical factors of landscape development which are visible in a space, and so are considered in relation to land cover/land use in Central Lika in this paper.

The database (CLC 2012) comprises digital data which refer to parts of the landscape (for example, settlement, pasture, lake etc.), and is divided into data classes. In this paper, all the digital data referring to the landscape of Central Lika were defined as landscape patches of Central Lika. For the purposes of this research, all data classes referring to the area of Central Lika were divided into various landscape types (for example, the data classes Pastures and Natural grasslands were classed under Grassland). On this basis, each landscape patch of Central Lika was assigned to one of the landscape types of Central Lika. At the same time, the landscape patches were assigned to individual landscape types, so that they were as homogeneous as possible in relation to each other in terms of their natural geographic features and the socio-geographic factors of landscape development which were evident in the researched space.

All the patches and landscape types of Central Lika used in this paper are available as digital data, and the spatial analysis was efficiently conducted using GIS methods. In fact, GIS technology enables and provides qualitative, accurate information about the landscape and its characteristics (Olahová et al. 2013), a higher speed and an entire series of additional qualitative and quantitative analyses which would be incredibly difficult to perform without GIS application. In addition, an analysis of landscape indicators forms a foundation for a comparison of various scenarios in the landscape, and provides insight into specific features of the landscape over time (Paudel and Yuan 2012).

\section{Previous Research}

Using different approaches and methods, landscapes and individual parts of landscapes have been studied in domestic and international papers from different aspects, by analysing the structure and function of landscapes over one or more periods of time.

When research is conducted on a landscape, patches or parts of the landscape are studied. Research papers show one or more levels of landscape (for example, subtype, type, and the landscape as a whole), while analyses are usually performed on one case study, for one separate area or in parallel on several case studies, for several different areas.

By applying GIS technology, Lang and Blaschke (2010) analysed three aspects of landscapes (structure, function and development) using various examples or landscapes, that is, using descriptive-analytical and empirical methods in turn. However, in the analysis of structural characteristics for landscape patches in Central Lika, this paper uses only one appropriate spatial analysis method for each of the observed characteristics (Shape Index for the shape, Average Nearest Neighbour for the position and Core Area for the condition). M. Jovanić (2017) also analysed all three mentioned aspects of landscape on one case study, the area of Central Lika. Using the methods of spatial analysis and regression analysis, she analysed the characteristics and development of the characteristics of the landscape patches in Central Lika for subtypes and types of landscapes and the landscape as a whole. In papers by other authors (for example, Rutledge 2003, Olahová et al. 2013), in addition to the above-mentioned spatial analysis methods, a number of others were used. Rutledge (2003) showed a model with a higher number of indicators which were applicable when analysing the patch fragmentation of the landscape, but did not conduct an analysis in a specific, defined area.

By using data for a specific point in time, some researchers have studied the current, modern structure

KiG No. 34, Vol. 19, 2020, https://doi.org/10.32909/kg.19.34.2 - - 
su i računalni alati, metode geografske obrade informacije, kao i obrada digitalnih slika koji su imali velik utjecaj u proučavanju strukture, odnosno razvoja krajolika (Lang i Blaschke 2010).

Pri utvrđivanju tipova krajolika postoje dva pristupa: na temelju zemljišnog pokrova/načina korištenja zemljišta i na temelju sinteze prirodnih i kulturnih obilježja korištenjem hijerarhijskog pristupa (Dumbović Bilušić 2015). Kao rezultat toga se, s obzirom na promatrana obilježja, utvrđuju što homogeniji prostorni dijelovi krajolika koji se svrstavaju u tipove krajolika.

Cilj ovog rada je, korištenjem odgovarajućih metoda prostorne analize, utvrditi pojedina strukturna obilježja (oblik, položaj i stanje) uzoraka krajolika Srednje Like prema tipovima krajolika za 2012. godinu te regresijskom analizom ustanoviti postoji li povezanost među njima.

Pri utvrđivanju tipova krajolika Srednje Like korišten je pristup koji se temelji na zemljišnom pokro$\mathrm{vu} /$ načinu korištenja zemljišta. Naime, korišteni su podatci iz baze podataka CORINE Land Cover iz 2012. godine (CLC 2012). Ti podatci ukazuju na prirodnogeografska obilježja i društveno-geografske čimbenike razvoja krajolika koji su vidljivi u prostoru i time su u radu razmatrani kao zemljišni pokrov/način korištenja zemljišta Srednje Like.

Baza podataka (CLC 2012) sastoji se od digitalnih podataka koji se zapravo odnose na dijelove krajolika (npr. naselje, pašnjak, jezero i sl.), a raspoređeni su u klase podataka. U ovom radu su svi ti digitalni podatci koji se odnose na područje Srednje Like definirani kao uzorci krajolika Srednje Like. Za potrebe ovog rada sve su klase podataka koje se odnose na područje Srednje Like raspoređene $u$ jedan od tipova krajolika (npr. klase podataka Pašnjaci i Prirodni travnjaci svrstane su u tip krajolika Travnato zemljište). Na temelju prethodnog može se reći kako su u ovom radu svi uzorci krajolika Srednje Like svrstani $u$ jedan od tipova krajolika Srednje Like. Pri tome se uzorke krajolika težilo rasporediti u pojedini tip krajolika tako da međusobno budu što homogeniji s obzirom na njihova prirodnogeografska obilježja i društveno-geografske čimbenike razvoja krajolika koji su vidljivi u prostoru.

Svi uzorci i tipovi krajolika Srednje Like korišteni u ovom radu su podatci u digitalnom obliku te je najpogodnijim načinom provedena prostorna analiza - upotrebom GIS-a. Naime, GIS tehnologija omogućava kvalitetne i točnije informacije o krajoliku i njegovim obilježjima (Olahová i dr. 2013) te veću brzinu i čitav niz dodatnih kvalitativnih i kvantitativnih analiza koje bi bez primjene GIS-a bile vrlo teško, odnosno nezamislivo provesti. Također, analize pokazatelja krajolika predstavljaju temelj za usporedbu različitih scenarija u krajoliku i za razumijevanje pojedinih obilježja krajolika tijekom vremena (Paudel i Yuan 2012).

\section{Dosadašnja istraživanja}

Krajolici, odnosno pojedini dijelovi krajolika se, koristeći različite pristupe i metode, istražuju u domaćim i inozemnim radovima s različitih aspekata, analizirajući kako strukturu tako i funkciju krajolika, odnosno kroz jedno vremensko razdoblje ili više njih.

Pri istraživanju krajolika proučavaju se uzorci ili dijelovi krajolika. U radovima se prikazuju jedna ili više razina krajolika (npr. podtip, tip, krajolik u cjelini), dok se analize provode najčešće na jednoj studijislučaju, odnosno za jedno izdvojeno područje ili pak usporedno na više studija-slučaja, odnosno za više različitih područja.

Lang i Blaschke (2010) primjenjujući GIS tehnologiju analizirali su sva tri navedena aspekta krajolika (struktura, funkcija i razvoj) na različitim primjerima, odnosno krajolicima primjenjujući naizmjence deskriptivnoanalitičku i empirijsku metodu. Međutim, u ovom radu se, pri analizi strukturnih obilježja uzoraka krajolika Srednje Like, za svako od promatranih strukturnih obilježja koristi samo jedna odgovarajuća metoda prostorne analize (Shape Index za oblik, Average Nearest Neighbour za položaj i Core Area za stanje). M. Jovanić (2017) također je analizirala sva tri navedena aspekta krajolika jedne studije-slučaja, područja Srednje Like. Pri tome je korištenjem metoda prostorne analize i regresijske analize analizirala obilježja i razvoj obilježja uzoraka krajolika Srednje Like za podtipove i tipove krajolika te krajolik u cjelini. U pojedinim radovima drugih autora (npr. Rutledge 2003, Olahová i dr. 2013) uz navedene metode prostorne analize koristi se i veći broj drugih. Tako je Rutledge (2003) prikazao model s većim brojem pokazatelja koji se mogu primijeniti pri analizi fragmentacije uzoraka krajolika, ali pri tome ne provodi i analizu na određenom konkretnom prostoru.

Upotrebom podataka za jednu vremensku točku, u pojedinim se radovima istražuje trenutačna, suvremena struktura krajolika. Túri (2010) proveo je analizu strukture krajolika na razini uzorka. Pri tome je metodama prostorne analize za dva područja usporedio rezultate čak 30 pokazatelja. Blaće (2015) analizirao je razvoj strukture krajolika općine Nadin korištenjem više od 20 pokazatelja. Međutim, u ovom radu za svako strukturno obilježje se radi preglednosti primijenjuje jedna odgovarajuća metoda prostorne analize te se navode primjereni atributni opisi kako bi se pobliže objasnili rezultati. Blaschke (2000) 
of the landscape. Túri (2010) conducted an analysis of the landscape structure at the patch level. The results of 30 indicators were compared using spatial analysis methods for two areas. Blaće (2015) analysed the development of the landscape structure of Nadin municipality using more than 20 indicators. However, for the sake of clarity, in research showed in this paper one appropriate spatial analysis method was used for each structural characteristic, and suitable attribute descriptions were provided in order to explain the results in more detail. Blaschke (2000) conducted an analysis of the landscape structure using multiple examples, and employed empirical methods when researching spatial-statistical GIS technology methods regarding the connectivity and optimisation of the spatial arrangement of landscape elements. However, by using data for single points in time, these papers also analysed their structural changes over time. For example, Aničić and Perica (2003), using the photographic content of karst agricultural areas, analysed the structural changes for single points in time over a given period.

By using data for multiple points in time, some authors have analysed changes and the development of the landscape during one or more time periods. Esbah (2009) analysed changes in structural characteristics of patches in an urban area City of Aydin, Turkey, in two observation years (1977 and 2002) by using a larger number of indicators or spatial analysis methods, but did not include the methods of Average Nearest Neighbour and Core Area which are applied in this paper. Cole et al. (2018) conducted an analysis of the change in land cover /land use on a case study for the territory of the United Kingdom, during multiple time frames (2000-2006, 2006-2012), based on data from the CORINE Land Cover database. However, they did not analyse any structural characteristics. Paudel and Yuan (2012) conducted a study about landscape development and the ecological consequences of building a metropolitan area of Saint Paul and Minneapolis in the United States with reference to specific years $(1975,1986,1998,2006)$. In their analysis, they used a variety of data (aerial photography, orthophoto maps, or multispectral satellite images and spatial planning documents). When analysing various objects through multiple points in time, domestic authors have used a variety of data and analysis methods for landscape research. Morić-Španić and Fuerst-Bjeliš (2017) determined the landscape types of a case study, the area of the island of Hvar by combining multiple data types in two observation years (a vegetation map (1975) and CORINE Land Cover,
Croatian Forestry data and digital orthophoto maps (2011)), and tracked landscape change trends in the observed period. This paper uses the GIS model, which has further applications regarding agricultural revitalisation opportunities. Cvitanović (2014) used remote sensing to conduct an analysis of changes in land cover/land use in a case study, area of Hrvatsko zagorje, for the time period 1991-2011. Cvitanović and Fuerst-Bjeliš (2018) analysed changes in land cover/land use in one particular area for the time period of 1991-2011, using remote sensing, GIS, regression analysis and qualitative methods, with the aim of analysing the socio-geographic factors of change. Jogun et al. $(2017,2019)$ used, among other, remote sensing methods and a simulation model for analysis and projection of land cover changes, when analysed land cover changes in the northern Croatia for the period 1981-2011, and Požega-Slavonia County for the period 1985-2013.

It is especially important to mention works which have analysed data over a time span of 250 years or more, when satellite images were not available and could not be analysed by remote sensing methods. Instead, various other kinds of sources from different time periods were used, which demanded a very specific work methodology. That works also include recent data, which means the time frame of the investigation is indeed extensive. For a 250-year time span, Olahová et al. (2013) mapped changes in land cover/land use in a case study, landslide Handlová in Slovakia. For more recent years (2003 and 2011), they analysed the changes in the structual characterics of patches of the area using a higher number of indicators. In the first part of their paper, Fuerst-Bjeliš et al. (2000) presented the results of research into anthropogenic influences on the Central Velebit environment over a longer time period (starting before the $17^{\text {th }}$ century) using the descriptive-analytical method. They performed a diachronic analysis and produced a model of periodization changes to compare individual indicators in various stages of the observed period and analyse their development. In the second part of the paper, based on establishing a synthetic criterion which comprised three geoecological parameters (relative height, length of slope, length index and relative height) and one aesthetic parameter (visibility), by using multi-variant cluster and discriminatory analysis, they conducted a geoecological evaluation of the landscape. At the same time, a land capability map was created (with six capability categories). Whilst researching landscape changes in individual areas in the Republic of Croatia

KiG No. 34, Vol. 19, 2020, https://doi.org/10.32909/kg.19.34.2 - - 
analizu strukture krajolika proveo je na većem broju primjera empirijskom metodom pri istraživanju prostorno-statističkih metoda GIS tehnologije $u$ smjeru povezanosti i optimizacije prostornog rasporeda elemenata krajolika. Međutim, korištenjem podataka za jednu vremensku točku u radovima se analiziraju i njihove strukturne promjene tijekom vremena, tako su primjerice Aničić i Perica (2003) korištenjem fotografskog sadržaja krških poljoprivrednih područja u jednoj vremenskoj točki analizirali njihove strukturne promjene tijekom vremena.

Korištenjem podataka za više vremenskih točaka, $u$ pojedinim radovima se analizira promjena, odnosno razvoj krajolika za jedno vremensko razdoblje ili više njih. Esbah (2009) analizirao je promjenu strukturnih obilježja uzoraka gradskog područja Aydin u Turskoj za dvije promatrane godine (1977. i 2002.) upotrebom većeg broja pokazatelja, odnosno metoda prostorne analize, no ne uključuje primjerice pri tome i metode Average Nearest Neighbour i Core Area, korištene u ovom radu. U radu Colea i dr. (2018) za više vremenskih razdoblja (2000-2006, 2006-2012) provedena je analiza promjene zemljišnog pokrova/načina korištenja zemljišta na studiji-slučaju za područje Ujedinjenog Kraljevstva, utvrdenih na temelju podataka baze CORINE Land Cover, no pri tome se ne analiziraju i strukturna obilježja. Paudel i Yuan (2012) iznose istraživanje o razvoju krajolika te ekološke posljedice izgradnje metropolitanskog područja Saint Paula i Minneapolisa u Sjedinjenim Američkim Državama za više godina $(1975,1986,1998$. i 2006.), a pri analizi koriste različite vrste podataka (aerosnimke, ortofoto i multispektralne satelitske snimke te prostornoplanske dokumente). Hrvatski autori $u$ istraživanjima krajolika kroz više vremenskih točki analiziraju različite objekte upotrebom različitih vrsta podataka i metoda analize. Morić-Španić i Fuerst-Bjeliš (2017) utvrdili su tipove krajolika na studiji-slučaju za područje otoka Hvara na temelju kombinacije više vrsta podataka za dvije različite godine. Koristeći vegetacijske karte (1975) i CORINE Land Cover, podatke Hrvatskih šuma i digitalnih ortofotosnimaka (2011) utvrdili su trendove promjene krajolika. U radu je primjenjen GIS model koji ima moguću aplikaciju kroz model revitalizacije poljoprivrede. Cvitanović (2014) je za razdoblje 1991-2011 primjenom daljinskih istraživanja također proveo analizu promjene zemljišnog pokrova/načina korištenja zemljišta na studiji-slučaju za područje Hrvatskog zagorja. Za isto područje i vremensko razdoblje Cvitanović i Fuerst-Bjeliš (2018) analizirali su promjene zemljišnog pokrova/načina korištenja zemljišta pri čemu su u metodologiju istraživanja uključena daljinska istraživanja, GIS, regresijska analiza i kvalitativne metode s ciljem analize društveno-geografskih čimbenika promjene. Jogun i dr. (2017 i 2019) su upotrebom, između ostalog, metoda daljinskih istraživanja i simulacijskog modela za analizu i projekciju promjena zemljišnog pokrova, analizirali promjene zemljišnog pokrova $u$ sjevernoj Hrvatskoj za razdoblje 1981-2011 i Požeško-slavonskoj županiji za razdoblje 1985-2013.

Posebno je potrebno izdvojiti radove u kojima se analiziraju podatci vremenskog raspona od 250 godina $i$ više, što je vrijeme za koje nisu dostupne satelitske snimke koje bi se analizirale metodama daljinskih istraživanja, već se nužno koriste različiti tipovi izvora iz različitih vremenskih razdoblja, što zahtijeva sasvim specifičnu metodologiju rada. U tim istraživanjima koriste se i recentni podatci te se time dobiva dobiva veliki vremenski raspon istraživanja. Olahová i dr. (2013) su za razdoblje od 250 godina kartografski utvrdili promjene zemljišnog pokrova/načina korištenja zemljišta na studiji-slučaju za područje klizišta Handlová u Slovačkoj. Za dvije recentnije godine (2003. i 2011.) analizirali su promjenu strukturnih obilježja uzoraka tog područja korištenjem većeg broja pokazatelja. U prvom dijelu rada Fuerst-Bjeliš i dr. (2000) deskriptivno-analitičkom metodom izneseni su rezultati istraživanja antropogenog utjecaja na okoliš središnjeg Velebita kroz duže vremensko razdoblje (od prije 17. stoljeća). Pri tome je napravljena dijakronijska analiza i model periodizacije promjena jer se uspoređuju pojedini pokazatelji različitih faza promatranog razdoblja i analizira se njihov razvoj. U drugom dijelu rada, na temelju uspostave sintetičkog kriterija koji se sastoji od tri geoekološka parametra (relativna visina, dužina padina, indeks dužine i relativne visine) i jednog estetskog parametra (otvorenost pogleda), korištenjem multivarijantne cluster i diskriminantne analize, provedena je geoekološka evaluacija krajolika. Pri tome je konstruirana bonitetna karta (šest bonitetnih kategorija). Pri istraživanju promjena krajolika pojedinih područja Republike Hrvatske kroz duži vremenski period u radovima se koristi, na primjer, komparativna analiza različitih izvora podataka. U istraživanju promjena okoliša na studiji slučaja za područje središnjeg dijela Dalmatinske zagore od sredine 18. stoljeća do danas, Fuerst-Bjeliš i dr. (2011) su primjenili kombinaciju narativnih, katastarskih i kartografskih izvora - topografske i ortofotokarte, a prostorna analiza je provedena primjenom GIS-a. To je istraživanje, započeto početkom 21. stoljeća (Fuerst-Bjeliš 2002, Fuerst-Bjeliš 2003, Fuerst-Bjeliš i dr. 2003), jedno od prvih u novijem razdoblju u Hrvatskoj u kojem se analiziraju promjene pejzaža za razdoblje od nekoliko stoljeća, koje koristeći izvore različite starosti uključuju GIS i ostale metode istraživanja. Na to se istraživanje nadovezuju i 
over a longer time period, authors have also made use, for example, of comparative analyses of various data sources. In research of environmental changes in a case study for the area of the central part of the Dalmatian hinterland from the middle of the $18^{\text {th }}$ century to the present day, Fuerst-Bjeliš et al. (2011) used a combination of narrative, cadastral and cartographic sources - topographic and orthophoto maps, while a spatial analysis was conducted using GIS technology to research landscape changes in one area from the mid- $18^{\text {th }}$ century onwards. This research, which began early in the $21^{\text {st }}$ century (Fuerst-Bjeliš 2002, Fuerst-Bjeliš 2003, Fuerst-Bjeliš et al. 2003), and was one of the first in modern times in Croatia to analyse changes in the landscape over a period of several centuries, making use of sources of different ages, including GIS technology and other research methods. More recent studies have followed, which including combined methods (along with GIS and other quantitative and qualitative methods) over shorter or longer time spans. Durbešić (2012) and Durbešić and Fuerst-Bjeliš (2016) conducted a spatial analysis of landscape changes in an area using GIS technology for a period from the $19^{\text {th }}$ century to today, using necessarily varied source categories and including an analysis of socio-geographical change factors. Blaće (2019) studied changes in forest cover in the case study of Ravni kotari, also for a period of greater time span, from the $19^{\text {th }}$ century, to the present day using GIS technology and correlation methods. This research also included socio-geographical factors of change.

In this paper, based on the example of Central Lika, in addition to a spatial analysis of landscape patches for a specific point in time or condition (2012), we conducted a linear regression analysis with the aim of explaining the interrelations of the observed indicators (average index of patch shape, average index of core area, and average nearest neighbour index). Regression analysis has been applied till now in various research projects, but with other data and other indicators. Nupp and Swihart (2000) conducted an analysis of the influence of patch fragmentation in a woodland on different species of small mammals. Analyses of the characteristics (for example, numbers, density and weight) of various species of small mammals in correlation with indicators of structural landscape patch variety, using logistical and multifaceted linear regression models have been carried out. For example, Pahernik (2000), and Faivre and Pahernik (2007), using the obtained values of spatial arrangement and density of sinkholes, performed a regression analysis to ascertain the correlation of characteristics (for example, density and numbers) of sinkholes and spatial features (for example, inclination, energy of the relief, azimuth, lie in relation to the points of the compass). A more extensive analysis was conducted, which gave a better insight into these correlations with other physical and geographical features (for example, geological age, morphology and others), but without using socio-geographic variables.

\section{Methodological Explanations}

\subsection{Methodological comments on the use of data on land cover/land use}

When ascertaining landscape types, this paper uses an approach based on land cover/land use. For this purpose, data from the CORINE Land Cover 2012 (CLC 2012) database were used. ${ }^{1}$ The CLC 2012 database was produced at the European level in the context of the Copernicus Land Monitoring Service project. The part of the database that relates to the Republic of Croatia was produced by the Croatian Agency for the Environment and Nature (HAOP). The data in the database for the Republic of Croatia are arranged in a digital database according to the current administrative-territorial organisation of the country.

The standard approach to creating the CLC database is based on the visual interpretation of satellite imagery according to the accepted CLC methodology. Between 1985 and 1990, the European Commission implemented the CORINE programme, creating an information system on the condition of the European environment, while methodologies were developed and agreed upon at the European level. Since the formation of the EEA (European Environment Agency) and the establishment of Eionet (European Environment Information and Observation Network), the coordination of the CORINE database, including updates, has been carried out by the European Environment Agency (CLC 2006 technical guidelines 2017).

Based on CLC methodology, data are created in a vector data model on a scale of 1:100 000, with a minimum polygon width of 100 metres for linear entities

\footnotetext{
${ }^{1}$ Since the study was conducted for over years and most of it is completed before the publication of the CLC data 2018, all the analysis in this paper are reduced to data 2012. Due to changes in the landscape (and processes on which they depend) occur on a time scale much longer than several years, a period of several years between the two publication of CLC data can not significantly affect the findings in the paper.
}

KiG No. 34, Vol. 19, 2020, https://doi.org/10.32909/kg.19.34.2 - - 
kasnija, recentnija istraživanja koja uključuju kombinirane metode (uz GIS i druge kvantitativne i kvalitativne metode) u kraćem ili duljem vremenskom rasponu. U radovima Durbešić (2012) te Durbešić i Fuerst-Bjeliš (2016) provedena je prostorna analiza promjena pejzaža također jedne izdvojene studije-slučaja u Dalmatinskoj zagori. Za područje planine Svilaje, za razdoblje od 19. stoljeća do suvremenog razdoblja, korištene su pri tome nužno različite kategorije izvora uz primjenu GISa. To je istraživanje također uključilo i analizu društveno-geografskih čimbenika promjene. Blaće (2019) istražio je promjene šumskog pokrova na studiji-slučaju Ravnih kotara, također za razdoblje većeg vremenskog raspona, od 19. stoljeća, do danas uz primjenu GIS-a i metode korelacije. I to je istraživanje uključilo društveno-geografske čimbenike promjene.

U ovom je radu na primjeru područja Srednje Like, osim prostorne analize uzoraka krajolika za jednu određenu vremensku točku odnosno stanje (2012.), provedena i linearno-regresijska analiza s ciljem objašnjenja međuodnosa promatranih pokazatelja (prosječnog indeksa oblika uzorka i prosječnog indeksa površine jezgre, odnosno prosječnog indeksa susjednosti). Regresijska analiza korištena je do sada u pojedinim radovima, ali s drugim podatcima i drugim pokazateljima. Tako su Nupp i Swihart (2000) proveli analizu utjecaja fragmentacije uzoraka šumskog zemljišta na obilježja različitih vrsta malih sisavaca. Provedene su analize obilježja (npr. prisutnost, gustoća i težina) različitih vrsta malih sisavaca u međuzavisnosti s pokazateljima strukturnih različitosti uzoraka krajolika, pri čemu su korišteni logistički i višestruki linearni regresijski modeli. Primjerice, $\mathrm{u}$ radovima Pahernika (2000) te Faivre i Pahernika (2007) s dobivenim vrijednostima prostornog rasporeda i gustoće ponikava, primijenjena je regresijska analiza s ciljem utvrđivanja međuzavisnosti obilježja (npr. gustoća, broj) ponikava i obilježja prostora (npr. nagib, energija reljefa, azimut, pružanje prema stranama svijeta). Također je provedena je i daljnja analiza pri kojoj su produbljeni ti odnosi s drugim fizičko-geografskim obilježjima (npr. geološka starost, morfologija i dr.), no bez društveno-geografskih varijabli.

\section{Metodološka objašnjenja}

\subsection{Metodološke napomene vezane uz upotrebu podataka zemljišnog pokrova/načina korištenja zemljišta}

U ovom radu je pri utvrđivanju tipova krajolika korišten pristup koji je temeljen na zemljišnom pokro$\mathrm{vu/načinu} \mathrm{korištenja} \mathrm{zemljišta.} \mathrm{U} \mathrm{tu} \mathrm{svrhu} \mathrm{korišteni} \mathrm{su}$ podatci koji su sadržani u bazi podataka CORINE Land
Cover 2012 (CLC 2012). ${ }^{1}$ Baza podataka CLC $2012 \mathrm{iz}-$ rađuje se na europskoj razini u okviru projekta Copernicus Land Monitoring Service. Dio te baze koji se odnosi na Republiku Hrvatsku proizvod je Hrvatske agencije za okoliš i prirodu (HAOP). Podatci za Republiku Hrvatsku u toj bazi organizirani su u digitalnu bazu podataka prema važećem administrativnoteritorijalnom ustroju.

Standardni pristup izrade baze podataka CLC temelji se na vizualnoj interpretaciji satelitskih snimaka prema prihvaćenoj CLC metodologiji. Naime, u razdoblju 1985.-1990. Europska komisija je primijenila program CORINE te je nastao informacijski sustav o stanju europskog okoliša, a metodologije su razvijene i dogovorene na razini EU-a. Nakon uspostave Europske agencije za okoliš (EEA) te osnivanja Europske informacijske i promatračke mreže za okoliš (Eionet), koordinaciju baza podataka CORINE, uključujući i ažuriranja, provodi Europska agencija za okoliš (CLC 2006 technical guidelines 2017).

Na temelju CLC metodologije stvaraju se podatci u vektorskom modelu podataka u mjerilu 1:100 000, minimalne širine 100 metara za linearne entitete (linije) i 25 ha za površinske entitete (poligone). Uz navedeni izvor podataka, odnosno metodu na kojoj se temelji, važno je napomenuti kako u bazu podataka nisu uneseni svi dijelovi. Tako, na primjer, kod tipa krajolika Izgrađeno zemljište zbog nezadovoljavanja kriterija dovoljne koncentracije objekata u odnosu na rezoluciju rešetke, nisu vidljiva manja naselja. Također, kod tipa krajolika Izgrađeno zemljište zbog nedovoljne širine objekta $u$ odnosu na rešetku, od prometnica je vidljiva samo autocesta, dok ostale nisu vidljive. U namjeri što vjernijeg definiranja tipova krajolika i uzoraka krajolika Srednje Like, podatci navedene baze su korišteni kao činjenični te su kao takvi analizirani $u$ radu.

Definirana CLC nomenklatura sadrži ukupno 44 klase podataka. To znači da je na europskoj razini raznolikost zemljišnog pokrova/načina korištenja zemljǐsta generalizirana na 44 klase podataka (Cole i dr. 2018).

Unutar baze podataka CLC 2012 za područje Srednje Like evidentirano je 19 klasa podataka koje su za

\footnotetext{
${ }^{1} \mathrm{~S}$ obzirom na to da se istraživanje provodilo više godina i najveći dio je završen prije objave CLC podataka za 2018. godinu, sve analize u radu su svedene na podatke iz 2012. godine. S obzirom na to da se promjene krajolika i procesi koji ih uvjetuju događaju na vremenskoj skali mnogo duljoj od reda veličine nekoliko godina, razdoblje od nekoliko godina između dviju objava CLC podataka ne može bitno utjecati na nalaze u radu.
} 
(lines) and 25 ha for surface entities (polygons). In addition to this data source and the method on which it is based, it is important to note that not all parts have been entered in the database. For example, when looking at the landscape type Built-up Land, smaller settlements are not visible because there is too low a concentration of objects in relation to grid resolution. Also, due to the insufficient width of objects in relation to the grid in the landscape type Built-up Land, only highways are visible, while other roads are not. In order to provide the most accurate definition of landscape types and landscape patches in Central Lika, data from the database were taken as factual and analysed as such in this paper.

The defined CLC nomenclature consists of 44 data classes. This means that at the European level, the diversity of land cover/land use is covered in 44 data classes (Cole et al. 2018).

From the CLC 2012 data base for Central Lika, 19 data classes were grouped into 6 landscape types for the purposes of this paper: Built-up Land, Grassland, Agricultural Land, Forestland, Succession of Scrub/Forests, Water Areas. However, as mentioned in the introduction, all the data in the database in question are actually parts of the landscape and those that refer to Central Lika are defined for the purposes of this paper as landscape patches in Central Lika. Also, since all the data in the CLC 2012 are organised in data classes, those concerning the area of Central Lika are classed as landscape types in Central Lika. ${ }^{2}$ This procedure resulted in landscape patches within a specified landscape type in Central Lika which were as homogeneous as possible, given their natural geographical features and the socio-geographical factors of landscape development which are visible in the space.

\footnotetext{
${ }^{2}$ After completing the procedure, the landscape type Built-up Land contains five data classes: Discontinuous urban fabric; Industrial or commercial units; Road and rail networks and associated land; Construction sites; Mineral extraction sites. The landscape type Grassland contains two data classes: Pastures; Natural Grassland. The landscape type Agricultural Land contains three data classes: Non-irrigated arable land; Mosaic farmland; Land principally occupied by agriculture, with a significant ratio of natural vegetation. The landscape type Forestland contains three classes: Deciduous forests, Coniferous forests, Mixed forests. The landscape type Succession of Scrub/Forests contains four data classes: Continental shrub-like vegetation (heaths, moors and low shrubbery); Mediterranean shrub-like vegetation (sclerophylous); Transitional woodland (land with overgrowth); Sparsely vegetated areas. The landscape type Water Areas contains two data classes: Water courses; Water bodies.
}

3.2 Methodological comments on spatial analysis methods used

An analysis was performed for this paper based on using various spatial analysis methods for landscape patches with the help of GIS technology. In doing so, the shape, position and condition of landscape patches were analysed in more detail, as was the landscape of Central Lika as a whole. In order to calculate indices for landscape structure in this research, the basic software package ArcGIS Desktop version 10.0 produced by ESRI was used.

The shape of landscape patches is determined by the Mean Shape Index (herein after: MSI). MSI is based on the spatial analysis method known as Shape Index, whose result is the application of a numerical shape index value (minimum, maximum and mean) for each of the observed sets. In this paper, MSI measured the mean patch shapes for each landscape type and for the landscape patches of Central Lika as a whole.

For the vector shape data, MSI is calculated using the formula (Land and Blaschke 2010):

$$
M S I=\frac{p}{2 \sqrt{\pi a}}
$$

where $p$ - circumference of patch, $a$ - surface area of patch

MSI refers to the deviation of the patch shape from a circle (Lang and Blaschke 2010). Thus, MSI measures the geometrical complexity of the patches - the greater the complexity, the greater the MSI value (Esbah 2009). Based on the patch complexity or MSI value, attributive descriptions are defined. ${ }^{3}$ If the shape of the observed set of patches is simple, that is, close to a circle, the MSI value is close to one (1). On the other hand, the more complex a shape of observed patch sets, the greater the MSI value. That means that elongated patches, corridors, spirals and other complex patch shapes have a higher MSI value than compact, rounded patches and patches with a simple shape.

The Core Area Index (herein after: CAI) is used to determine landscape patch condition. This is obtained by calculating the data from each patch in the observed set (for all landscape types and for the

\footnotetext{
${ }^{3}$ Based on the values of the mean shape index, four categories of patch shape are defined: simple $(0 \leq \mathrm{MSI} \leq 2,00)$; complex $(2,01 \leq$ MSI $\leq 4,00)$; more complex $(4,01 \leq$ MSI $\leq$ 6,00 ), and very complex (MSI $\geq 6,01$ ).
}

KiG No. 34, Vol. 19, 2020, https://doi.org/10.32909/kg.19.34.2 - 
potrebe ovog rada svrstane $u$ šest tipova krajolika: $I z-$ građeno zemljište, Travnato zemljište, Poljoprivredno zemlišste, Šumsko zemljište, Grmlje i sukcesija šume, Vodene površine. Naime, kako je u Uvodu ovog rada navedeno, svi podatci u toj bazi podataka su zapravo dijelovi krajolika, a oni koji se odnose na područje Srednje Like su za potrebe ovog rada definirani kao uzorci krajolika Srednje Like. Također, s obzirom na to da su svi podatci u bazi podataka CLC 2012 raspoređeni u klase podataka, one koje se odnose na područje Srednje Like su za potrebe ovog rada svrstane u tipove krajolika Srednje Like. ${ }^{2}$ Provedeni postupak rezultirao je time da su uzorci krajolika unutar pojedinog tipa krajolika Srednje Like što homogeniji s obzirom na njihova prirodnogeografska obilježja i društveno-geografske čimbenike razvoja krajolika koji su vidljivi u prostoru.

\subsection{Metodološke napomene vezane uz korištene metode prostorne analize}

U radu je provedena analiza koja se temelji na korištenju različitih metoda prostorne analize na uzorcima krajolika pomoću GIS tehnologije. Pri tome se detaljnije analiziraju oblik, položaj i stanje uzoraka krajolika za tipove krajolika te za krajolik Srednje Like u cjelini. U radu je za izračunavanje pokazatelja za strukturu krajolika korišten osnovni softverski programski paket ArcGIS Desktop verzije 10.0 proizvođača ESRI.

Oblik uzoraka krajolika ustanovljen je na temelju prosječne vrijednosti indeksa oblika (engl. Mean Shape Index, dalje u tekstu MSI). MSI se temelji na metodi prostorne analize engleskog naziva Shape Index, čiji je rezultat primjene numerička vrijednost indeksa oblika (minimalna, maksimalna i prosječna) za svaki od promatranih skupova. U ovom radu MSI mjeri

\footnotetext{
${ }^{2}$ Nakon provedenog postupka tip krajolika Izgrađeno zemljište sadrži pet klasa podataka: Nepovezana gradska područja; Industrijski ili komercijalni objekti; Cestovna i željeznička mreža i pripadajuće zemljište; Gradilišta; Mjesta eksploatacije mineralnih sirovina. Tip krajolika Travnato zemljište sadrži dvije klase podataka: Pašnjaci; Prirodni travnjaci. Tip krajolika Poljoprivredno zemljište sadrži tri klase podataka: Nenavodnjavano obradivo zemljište; Mozaik poljoprivrednih površina; Pretežno poljoprivredno zemljište, sa značajnim udjelom prirodnog biljnog pokrova. Tip krajolika Šumsko zemljište sadrži tri klase podataka: Bjelogorična šuma; Crnogorična šuma; Mješovita šuma. Tip krajolika Grmlje i sukcesija šume sadrži četiri klase podataka: Kontinentalna grmolika vegetacija (vrištine, cretovi i niske šikare); Mediteranska grmolika vegetacija (sklerofilna); Sukcesija šume (zemljišta u zarastanju); Područja s oskudnom vegetacijom. Tip krajolika Vodene površine sadrži dvije klase podataka: Vodotoci; Vodna tijela.
}

prosječan oblik uzoraka svakog tipa krajolika te uzoraka krajolika Srednje Like u cjelini.

MSI se za podatke vektorskog oblika dobiva na temelju formule (Lang i Blaschke 2010):

$$
M S I=\frac{p}{2 \sqrt{\pi a}}
$$

gdje je $p$ - opseg uzoraka, $a$ - površina uzoraka

MSI se odnosi na odstupanje oblika uzorka od oblika kruga (Lang i Blaschke 2010). Time MSI mjeri geometrijsku složenost uzoraka - veća složenost uzoraka znači veće vrijednosti MSI (Esbah 2009). Na temelju složenosti uzoraka, odnosno na temelju vrijednosti MSI u radu su definirani atributni opisi. ${ }^{3}$ Ukoliko je oblik promatranog skupa uzoraka jednostavniji, tj. sličniji je obliku kružnice, vrijednost MSI je bliža vrijednosti jedan (1). S druge strane, što je složeniji oblik promatranog skupa uzoraka, to je vrijednost MSI veća. To znači da uzorci linearnog oblika, oblika koridora te uzorci spiralnog i složenog oblika imaju veću vrijednost MSI od kompaktnih i zaobljenih uzoraka te uzoraka jednostavnog oblika.

Za stanje uzoraka krajolika korišten je pokazatelj indeks površine jezgre (engl. Core Area Index, dalje u tekstu CAI) koji je izračunan na temelju podataka svakog uzorka u promatranom skupu (za tipove krajolika i krajolik Srednje Like u cjelini). CAI je numerička vrijednost koja označava omjer površine jezgre (engl. Core Area, dalje u tekstu CA) i ukupne površine za svaki od promatranih skupova. Pri tome, što je dobivena numerička vrijednost CAI manja, to znači da je rezultat veće fragmentacije unutarnjih područja, tj. da je riječ o složenim ili izduženim oblicima jer je površina jezgre uzoraka manja, i obratno.

CA se dobiva kao rezultat primjene GIS metode za CA uzoraka kojom se dobiva numerička vrijednost ( $\mathrm{u}$ ovom radu $\mathrm{u} \mathrm{km}^{2}$ ) koja se odnosi na ukupni CA za svaki od promatranih skupova. Može se reći kako je CA, u tehničkom smislu, jednak opciji prikaza prema unutrašnjosti metodi prostorne analize Buffer.

Sintaksa naredbenog retka za Buffer je (ESRI, 2020):

Buffer_analysis $<$ in_features $><$ out_feature_class $>$ $<$ buffer_distance_or_field $>$ FULL $\mid$ LEFT $\mid$ RIGHT $\mid$ OUTSIDE_ONLY\} \{ROUND |FLAT $\}$ NONE |ALL|LIST $\}$ \{dissolve_field;dissolve_field...\}

CA uzoraka zapravo označava središnji prostor uzoraka koji nije pod vanjskim utjecajima, dakle

\footnotetext{
${ }^{3} \mathrm{Na}$ temelju vrijednosti prosječnog indeksa oblika definirane su četiri kategorije oblika uzoraka: jednostavan $(0 \leq \mathrm{MSI} \leq$ 2,00); složen $(2,01 \leq \mathrm{MSI} \leq 4,00)$; složeniji $(4,01 \leq \mathrm{MSI} \leq$ 6,00 ); vrlo složen (MSI $\geq 6,01$ ).
} 
landscape of Central Lika as a whole). CAI is a numerical value which describes the ratio of the Core Area, herein after: $\mathrm{CA}$ ) and the total area for each of the observed sets. The smaller the numerical value of CAI, the greater the fragmentation of the inner areas, that is, they must be complex or elongated objects because the core area of the patches is smaller, and vice versa.

$\mathrm{CA}$ is obtained as the result of applying the GIS method for CA patches and is a numerical value (in this paper expressed in $\mathrm{km}^{2}$ ) which refers to the total CA for each of the observed sets. In the technical sense, CA may be said to be equal to the inward depiction option of the spatial analysis method Buffer.

The command-line syntax for Buffer is (ESRI 2020):

Buffer_analysis <in_features> <out_feature_class> $<$ buffer_distance_or_field> \{FULL | LEFT | RIGHT | OUTSIDE_ONLY\} \{ROUND | FLAT $\}$ \{NONE | ALL | LIST \} \{dissolve_field;dissolve_field...\}

The CA of the patches in fact denotes the central patch area which is not exposed to external influences, that is, the patch area without the margins. It is important to note that the size of the patch margins (the influence of the exterior towards the core) depends on the object being studied. The issue concerns establishing effectively used areas depending on the context. While researching small mammals in a woodland, Nupp and Swihart (2000) used a distance to the margin of 50 metres. While researching landscape patches for two different parts of the landscape Túri (2010) used a distance to the margin of 10 metres. Lang and Blaschke (2010) used distances of $5 \mathrm{~m}, 10 \mathrm{~m}, 20 \mathrm{~m}, 35 \mathrm{~m}$ and $50 \mathrm{~m}$ according to various examples. For the purposes of this paper and the level of generalisation of the data used $(100 \mathrm{~m})$, we used a distance of 50 metres for all landscape types and the landscape of Central Lika as a whole.

The position of landscape patches was studied based on the GIS method of Average Nearest Neighbour (Spatial Statistics), herein after: Average Nearest Neighbour. By determining the radius of distance by which the classification of intensity around every observed element can be determined (Pahernik 2000), this method was implemented in order to ascertain the average distance between each observed landscape patch and its nearest neighbour. This also determined the grouping, randomness and dispersion of the observed landscape patches.

The near neighbour analysis using this method was conducted using vector data, taking into consideration all patches according to landscape type, and the landscape of Central Lika as a whole. On the other hand, in other research (for example, Faivre and Pahernik 2007, Pahernik 2000, 2012), it was conducted using a raster data model which only looked at sinkholes.

One version of this method was chosen, according to which the landscape patches are turned into points or centroids in advance. The distance between the centroids of each patch and the location of the nearest neighbouring centroid is measured, then the average of all measured distances is calculated (ESRI 2019).

Average Nearest Neighbor is obtained by calculation based on formulas (ESRI 2020):

$$
\begin{aligned}
& A N N=\frac{\bar{D}_{O}}{\bar{D}_{E}} \\
& \bar{D}_{O}=\frac{\sum_{i=1}^{n} d_{i}}{n} \\
& \bar{D}_{E}=\frac{0.5}{\sqrt{n / A}} \\
& z_{A N N}=\frac{\bar{D}_{O}-\bar{D}_{E}}{S E} \\
& S E=\frac{0.26136}{\sqrt{n^{2} / A}}
\end{aligned}
$$

$\bar{D}_{0}$ - observed mean distance between each feature and their nearest neighbor

$\bar{D}_{E}$ - expected mean distance for the features given a random pattern

$d_{i}$ - equals the distance between feature $i$ and its nearest feature

$n$ - total number of features

$A$ - total study area

$z_{\mathrm{ANN}}-z$-score for Average Nearest Neighbor

The results of applying this GIS method are the following values: Observed Mean Distance, ${ }^{4}$ Expected Mean Distance, Nearest Neighbour Ratio, $z$-value and $p$ value. ${ }^{5}$ If the value of the Nearest Neighbour Ratio is less than one (1), this indicates grouping. If it is greater than one (1), it indicates the dispersion of the landscape patches. Based on the obtained values, by using this spatial analysis method, attributive descriptions

\footnotetext{
${ }^{4}$ For the purposes of the regression analysis, the values of observed mean distance are used in this paper as indicators of the position of landscape patches.

${ }^{5}$ The $p$-value indicator indicates whether the observed phenomenon was random. If the $p$-value is smaller than the minimum value (0.05), the results are not random and are analysed in this paper.
}

KiG No. 34, Vol. 19, 2020, https://doi.org/10.32909/kg.19.34.2 - 
označava područje uzorka bez rubnog dijela. Pri tome je važno napomenuti kako veličina rubnog dijela (utjecaj izvana prema jezgri) uzorka ovisi o objektu istraživanja. Naime, riječ je o utvrđivanju efektivno korištenih površina u ovisnosti o kontekstu. Tako su Nupp i Swihart (2000) pri istraživanju malih sisavaca na šumskom zemljištu koristili udaljenost rubnog dijela od 50 m. Túri (2010) pri istraživanju uzoraka krajolika za dva različita dijela krajolika koristio je udaljenost rubnog dijela od $10 \mathrm{~m}$. Lang i Blaschke (2010) na različitim primjerima koristili su udaljenosti rubnog dijela od $5 \mathrm{~m}, 10 \mathrm{~m}, 20 \mathrm{~m}, 35 \mathrm{~m}$ i $50 \mathrm{~m}$. U ovom radu se zbog svrhe rada te razine generaliziranosti podataka (100 $\mathrm{m}$ ) koristi udaljenost rubnog dijela od $50 \mathrm{~m}$ za sve tipove krajolika i krajolik Srednje Like u cjelini.

Položaj uzoraka krajolika istražen je na temelju prosječnog indeksa susjednosti, korištenjem metode Average Nearest Neighbour (Spatial Statistics), dalje u tekstu Average Nearest Neighbour. Temeljem određivanja radijusa udaljenosti pri čemu se određuje klasifikacija intenziteta oko svakog promatranog elementa (Pahernik 2000), ta metoda primijenjena je u svrhu utvrđivanja prosječne udaljenosti svakog od promatranih uzoraka krajolika prema najbližem susjednom. Pri tome se utvrđuje grupiranje, nasumičnost, odnosno raspršenost promatranih uzoraka krajolika.

Takva analiza susjedstva u ovom se radu provodi s vektorskim podatcima, uzimajući u obzir sve uzorke po tipovima krajolika, te krajolik Srednje Like u cjelini. S druge strane, u pojedinim radovima (npr. Faivre i Pahernik 2007, Pahernik 2000, 2012) provodi s rasterskim modelom podataka pri čemu se promatraju samo ponikve.

Korištena je opcija te metode pri kojoj su uzorci krajolika prethodno pretvoreni $\mathrm{u}$ točke, odnosno centroide. Pri tome se mjeri udaljenost između lokacije centroida svakog uzorka i lokacije najbližeg susjednog centroida te se zatim mjeri prosjek svih izmjerenih udaljenosti (ESRI, 2019). Average Nearest Neighbour se računa po formuli (ESRI 2019):

$$
\begin{aligned}
& A N N=\frac{\bar{D}_{O}}{\bar{D}_{E}} \\
& \bar{D}_{O}=\frac{\sum_{i=1}^{n} d_{i}}{n} \\
& \bar{D}_{E}=\frac{0,5}{\sqrt{n / A}} \\
& z_{\text {ANN }}=\frac{\bar{D}_{O}-\bar{D}_{E}}{S E}
\end{aligned}
$$

$S E=\frac{0,26136}{\sqrt{n^{2} / A}}$

$\bar{D}_{0}$ - uočena srednja udaljenost između svakog uzorka i najbližeg susjednog

$\bar{D}_{E}$ - očekivana srednja udaljenost za nasumične uzorke

$d_{i}$ - udaljenost između uzorka $i$ i najbližeg susjednog

$n$ - ukupan broj uzoraka

$A$ - područje istraživanja

$z_{\text {ANN }}-z$-vrijednost za Average Nearest Neighbour

Rezultat primjene te metode su vrijednosti: uočena srednja udaljenost (engl. Observed Mean Distance), ${ }^{4}$ očekivana srednja udaljenost (engl. Expected Mean Distance), omjer najbliže udaljenosti (engl. Nearest Neighbour Ratio), $z$-vrijednost i $p$-vrijednost. ${ }^{5}$ Ukoliko je vrijednost omjera najbliže udaljenosti manja od vrijednosti jedan (1) - ukazuje na grupiranje, a ako je veća od vrijednosti jedan (1) - ukazuje na raspršenost uzoraka krajolika. Na temelju dobivenih vrijednosti, korištenjem te metode prostorne analize automatski su prikazani atributni opisi (grupirano, nasumično, raspršeno) koji su u radu navedeni i objašnjeni.

\section{Područje istraživanja}

Područje istraživanja ovog rada je Srednja Lika. Prema aktualnoj administrativno-teritorijalnoj organizaciji, Srednja Lika obuhvaća područje tri jedinice lokalne samouprave: Grad Gospić, Općinu Lovinac i Općinu Perušić, koje su sastavni dio Ličko-senjske županije. Ukupna površina područja istraživanja iznosi približno $1690 \mathrm{~km}^{2}$. Na području istraživanja nalazi se 78 naselja - Gradu Gospiću pripada 50 naselja, Općini Perušić pripada 18 naselja i Općini Lovinac pripada 10 naselja.

Osnovu regionalne izdvojenosti Srednje Like čini orografski okvir kojeg sačinjavaju: gorski hrbat Velebit sa zapadne i jugozapadne strane, Ličko sredogorje s istočne strane i gorski masiv Resnik s jugoistočne strane. Središnji prostor Srednje Like odnosi se na Ličko polje, koje se smatra najvećim krškim poljem na području Republike Hrvatske. Jugoistočni dio istraživanog područja zauzima Lovinačko polje. Od

\footnotetext{
${ }^{4} \mathrm{U}$ radu su u svrhu regresijske analize kao pokazatelj za položaj uzoraka krajolika korištene vrijednosti uočene srednje udaljenosti.

${ }^{5}$ Vrijednosti pokazatelja $p$-vrijednost označavaju razlikuje li se promatrana pojava od slučajne. Ukoliko $p$-vrijednost iznosi manje od granične vrijednosti $(0,05)$, ti rezultati se razlikuju od slučajnih te su analizirani u radu.
} 


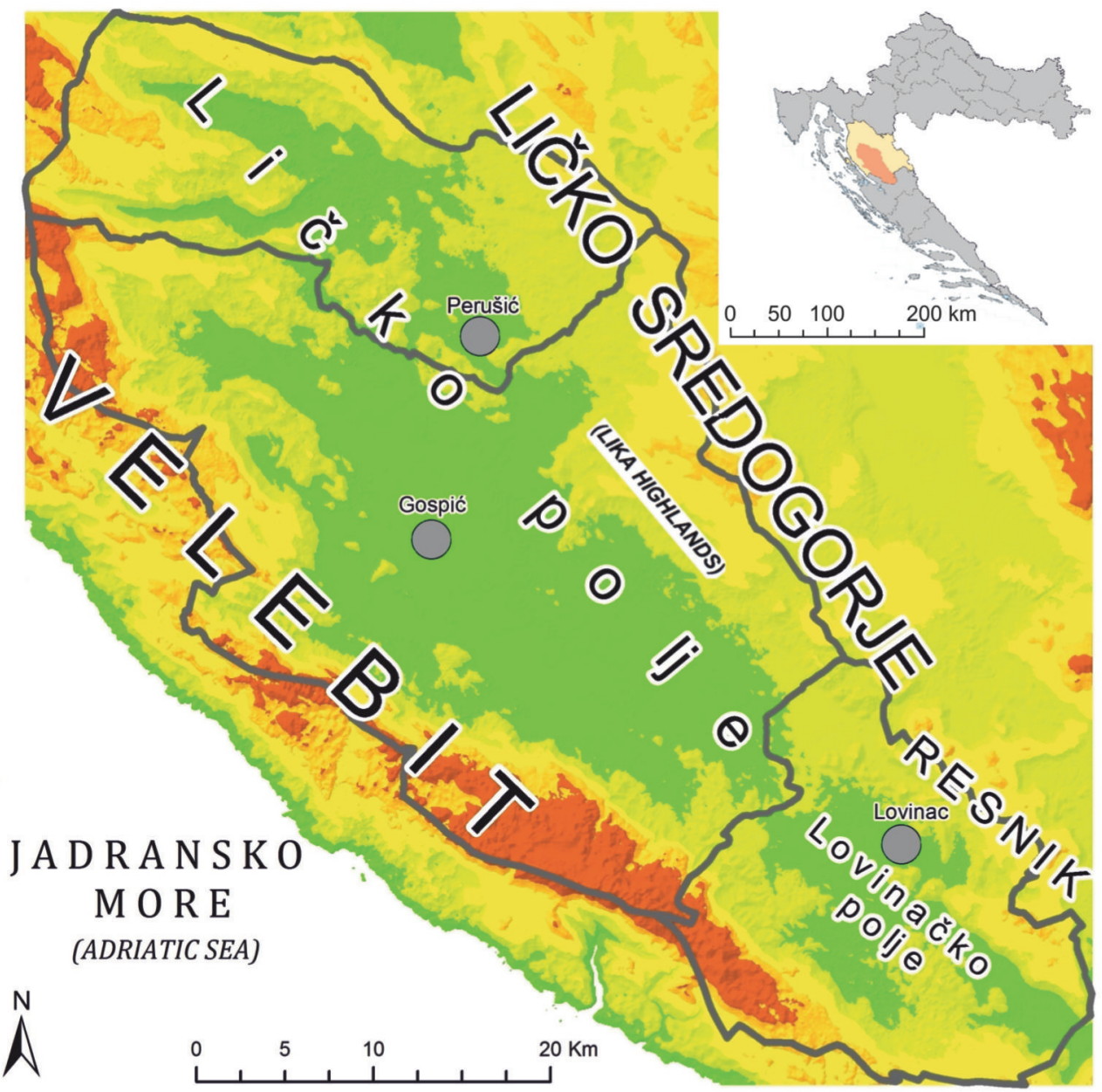

\section{Nadmorska visina (m) Altitude above sea level (in meters)}

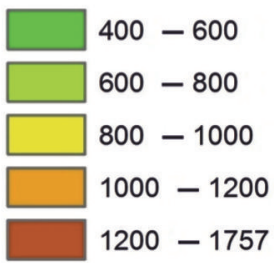

Granica grada/općine
Town/municipal boundary

Autorica Marta Hamzić Author Marta Hamzić

Fig. 1 Research area - Central Lika. Source: DARH, SGA; SRPJ, SGA.

Slika 1. Područje istraživanja - Srednja Lika. Izvori: DARH, DGU; SRPJ, DGU.

are automatically shown (grouped, random, dispersed), as listed and explained in this paper.

\section{Research Area}

The research area in this paper was Central Lika. According to current administrative-territorial organisation, Central Lika covers an area of three units of local self-government: the town of Gospić, the municipality of Lovinac and the municipality of Perušić which are integral constituents of Lika-Senj County. The total research area covers approximately $1,690 \mathrm{~km}^{2}$. There are 78 settlements located within the research area, 50 of which belong to the town of Gospić, 18 to the municipality of Perušić, and 10 to the municipality of Lovinac.

The basis for Central Lika's regional distinctness is an orographic framework comprising the mountainous ridge of Velebit to the west and southwest, the Lika highlands to the east, and the mountainous Resnik massif on the southeast side. The middle part of Central Lika is formed by Ličko polje, which is considered the largest karst field in the Republic of Croatia. The southeast part of the research area is mostly occupied by Lovinačko polje. It is separated from the rest of Central Lika by conical hummocks, or elevations in the karst (Figure 1).

The range of altitudes above sea level in the research area is $461 \mathrm{~m}$ to $1,757 \mathrm{~m}$, and the average altitude is $740 \mathrm{~m}$ (Pahernik and Jovanić, 2014). The settlements and areas of human activity in Central Lika are mainly concentrated in the central area Ličko polje (Lika Field).

The artificial surfaces and areas of human activity occupy a total of $17.05 \%$ of the surface area of Central Lika. The total artificial area is $1.29 \%$ and KiG No. 34, Vol. 19, 2020, https://doi.org/10.32909/kg.19.34.2 - - 
ostatka područja Srednje Like odvojeno je kupastim humovima, odnosno uzvišenjima u kršu (slika 1).

Raspon nadmorske visine područja istraživanja je između 461 i $1757 \mathrm{~m}$, a prosječna nadmorska visina iznosi 740 m (Pahernik i Jovanić 2014). Naselja i područja čovjekovog djelovanja Srednje Like uglavnom su koncentrirana na središnjem prostoru - Ličkom polju.

Izgrađene površine te područja čovjekovog djelovanja zauzimaju ukupno 17,05 \% površine Srednje Like. Naime, ukupna izgrađena površina iznosi 1,29 \% površine Srednje Like. To se odnosi na ukupnu površinu naselja Srednje Like ${ }^{6}$ koja iznosi 0,66 \% površine te na $0,63 \%$ površine koja se odnosi na površine objekata s prometnom i gospodarsko-poduzetničkom djelatnosti (autocesta i pripadajuće zemljište, poduzetničke zone, gradilišta i mjesta eksploatacije mineralnih sirovina). Na poljoprivredno zemljište odnosi se ukupno 15,76 \% površine Srednje Like (CLC 2012).

\section{Strukturna obilježja uzoraka krajolika Srednje Like prema tipovima krajolika}

Prema postupku navedenom prethodno $u$ radu, na temelju podataka o zemljišnom pokrovu/načinu korištenja zemljišta iz 2012. godine, područje Srednje Like svrstano je u šest tipova krajolika (slika 2):

1. Izgrađeno zemljište

2. Travnato zemljište

3. Poljoprivredno zemljište

4. Šumsko zemljište

5. Grmlje/sukcesija šume

6. Vodene površine

Na uzorcima tipova krajolika provedene su analize koje se temelje na više pokazatelja i korištenju metoda prostorne analize. Njihovom primjenom dobivene su vrijednosti za oblik, položaj i stanje uzoraka tipova krajolika Srednje Like i krajolik Srednje Like u cjelini. Sve dobivene vrijednosti su prikazane u tablici 1.

\footnotetext{
${ }^{6}$ Podatci se odnose na bazu podataka Corine Land Cover 2012 (CLC 2012) prema kojoj se prikazuju samo veća naselja: Gospić (prikazan je s naseljima: Budak, Žabica, Kaniža Gospićka, Podoštra), Lički Osik, Perušić, Mušaluk, Donji Kosinj, Lički Novi, Bilaj i Lovinac. Ostala naselja nalaze se na manjoj površini, odnosno imaju manju koncentraciju izgrađenosti. To su uglavnom raštrkana naselja koja se uglavnom sastoje od nekoliko zaselaka zbog krške prirodne osnove i nasljeđenih obilježja historijsko-geografskog razvoja. Naime, stvaranje niznih naselja, koje je započelo u 18. stoljeću (kada je područje Srednje Like bilo je u sastavu Vojne krajine, odnosno pod austrijskom upravom) i ponovno je intenzivirano industrijalizacijom i urbanizacijom nakon završetka Drugog svjetskog rata, dalo je ograničene rezultate.
}

Napomena: U poglavlju „Metodološke napomene vezane uz korištene metode prostorne analize“ detaljno su objašnjene korištene metode i značenja atributnih opisa.

Tip krajolika Izgrađeno zemliište na području Srednje Like sastoji se od ukupno 17 uzoraka. Taj tip krajolika pretežno je položen bliže središnjem dijelu. Sadrži naselja s većim brojem stanovnika, odnosno naselja s većom koncentracijom izgrađenosti te objekte s prometnom i gospodarsko-poduzetničkom djelatnosti (autocesta i pripadajuće zemljište, poduzetničke zone, gradilišta i mjesta eksploatacije mineralnih sirovina). Vrijednost MSI je među ostalim tipovima krajolika najveća $(4,19)$. S obzirom na tu vrijednost, oblik uzoraka tog tipa krajolika može se opisati kao složeniji. To je naročito izraženo kod izduženih uzoraka, kao što je autocesta i pripadajuće zemljište. Među ostalim tipovima krajolika Srednje Like, kod tipa krajolika Izgrađeno zemljište vrijednost CAI je najmanji (43,91\%). Naime, kod tog tipa krajolika je najveći broj uzoraka sa složenim ili izduženim oblikom zbog čega je površina jezgre uzoraka najmanja. S obzirom na položaj uzoraka tog tipa krajolika, riječ je o raspršenom položaju uzoraka. To znači da je na području Srednje Like kod tog tipa krajolika prosječno velika udaljenost središta uzorka do središta susjednog uzorka.

Tip krajolika Travnato zemljište na području Srednje Like sastoji se od ukupno 99 uzoraka. Na području Srednje Like taj se tip krajolika odnosi na pašnjake i prirodne travnjake, koji se razvijaju kao rezultat prve faze sukcesije vegetacije. Naime, od završetka Drugoga svjetskog rata stvorena je „osnovna infrastruktura i provedena inicijalna industrijalizacija regije“ (Pejnović 1985:66) i započeo je složeniji gospodarski razvoj. Time se, u skladu s društveno-gospodarskim procesima (deagrarizacija, deruralizacija, urbanizacija, smanjenje ukupnog broja stanovnika, starenje stanovništva) stanovništvo Srednje Like sve manje bavi poljoprivredom. Zapuštanje, odnosno ekstenzifikacija korištenja poljoprivrednih površina i napuštanje njihove obrade dovodi do prirodnog procesa sukcesije vegetacije, tj. prirodnog pošumljavanja (Fuerst-Bjeliš i dr. 2000). U prvoj fazi sukcesije vegetacije na poljoprivrednom zemljištu izrasta nisko raslinje koje se može nazvati travnatim zemljištem. Zatim, ukoliko dođe do druge faze sukcesije, na travnatom zemljištu se razvija srednje visoko raslinje - grmlje, odnosno sukcesija šume. Iz takvog srednje visokog raslinja se u završnoj, trećoj fazi sukcesije vegetacije postepeno razvija visoko raslinje - šumsko zemljište.

Obilježja tipa krajolika Travnato zemljište su različite vrste trava koje nisu visokog rasta djelomično zbog ispaše stoke (pašnjaci) i djelomično zbog prirodnih preduvjeta (prirodni travnjaci). Pašnjaci se uglavnom 
refers to the total area of human settlements ${ }^{6}$, which amounts to $0.66 \%$ of the area, while $0.63 \%$ of the area refers to transport facilities and economic-entrepreneurial activities (motorways and associated land, entrepreneurial zones, construction sites and mineral exploitation sites). Agricultural land covers a total of $15.76 \%$ of the area of Central Lika (CLC 2012).

\section{Structural Characteristics of Landscape Patches in Central Lika According to Landscape Type}

According to the procedure mentioned earlier in the paper, based on data on land cover/land use from 2012, the area of Central Lika is classified in six landscape types (Figure 2):

1. Built-up Land

2. Grassland

3. Agricultural Land

4. Forestland

5. Succession of Scrub/Forests

6. Water Areas

Based on several indicators and the use of spatial analysis methods, analyses were performed on patches of landscape types. By applying them, values were obtained for the shape, position and condition of patches of landscape types in Central Lika and the landscape of Central Lika as a whole. The obtained values are shown in Table 1.

Comments: In the section Methodological comments on spatial analysis used the applied methods and meaning of attributive descriptions are explained in detail.

The landscape type Built-up Land in the area of Central Lika comprises a total of 17 patches. This landscape type is mostly situated close to the central part. It includes settlements with a higher number of inhabitants, that is, settlements with a higher concentration of buildings, transport facilities and economic-entrepreneurial activities (motorways

\footnotetext{
${ }^{6}$ The data relate to the Corine Land Cover 2012 (CLC 2012) database, according to which only larger settlements are shown: Gospić (shown with the settlements of Budak, Žabica, Kaniža Gospićka, Podoštra), Lički Osik, Perušić, Mušaluk, Donji Kosinj, Lički Novi, Bilaj and Lovinac. Other settlements occupy a smaller area, that is, they have a lower concentration of construction. These are mostly scattered (dispersed) settlements that consist of several hamlets, due to the karst nature of the land and the inherited features of historical and geographical development. In fact, the creation of the low-lying settlements, which began in the 18th century (when the area of Central Lika was part of the Military Frontier under Austrian rule) and intensified through industrialization and urbanization after the Second World War, produced only limited results.
}

and associated land, entrepreneurial zones, construction sites and mineral exploitation sites). The MSI value is highest compared to other landscape types (4.19). Given this value, the shape of the patches in this landscape type can be described as more complex. This is particularly pronounced in elongated patch examples such as the highway and its associated land. Among other landscape types in Central Lika, the category of Built-up Land has the lowest CAI value (43.91\%). In this landscape type, the highest number of patches are complex or elongated, which is why the surface area of the core of the patches is the smallest. In terms of the position of the patches of this landscape type, they are dispersed. This means that in the area of Central Lika, for this landscape type, there is an averagely great distance between the centre of the patch and the centre of the nearest neighbouring patch.

The landscape type Grassland in Central Lika comprises a total of 99 patches. In the area of Central Lika, this landscape type refers to pastures and natural grasslands which have developed as a result of the first phase of vegetation succession. After the end of the Second World War, "basic infrastructure was created and the initial industrialisation of the region was carried out" (Pejnović 1985: 66). More complex economic development was launched. Thus, in accordance with socio-economic processes (deagrarisation, deruralisation, urbanisation, reduction of the total population and ageing of the population), the population of Central Lika has become less and less engaged in agriculture. Abandoning the land, or rather the extensification of agricultural land and neglect of cultivation, has led to a natural process of vegetation succession or natural afforestation (Fuerst-Bjeliš et al., 2000). In the first phase of vegetation succession, low-growing plants take over agricultural land, forming grassland. In the second phase, mediumhigh vegetation develops on the grassland - shrubs and forest undergrowth. In the final, third phase, trees and forests thrive.

The landscape-type characteristics of Grassland include a variety of grasses that do not grow tall, partly due to cattle grazing (pastures) and partly due to natural conditions (natural grasslands). Pastures are mostly located in areas away from settlements, because arable land is found next to settlements. Natural grasslands are located on mountain slopes, but also in the lowland areas (in Ličko polje on the west side of the highway). The MSI value is one of the lowest among other landscape types (2.66), because in this type, the average shape of the patch is among

KiG No. 34, Vol. 19, 2020, https://doi.org/10.32909/kg.19.34.2 - - 


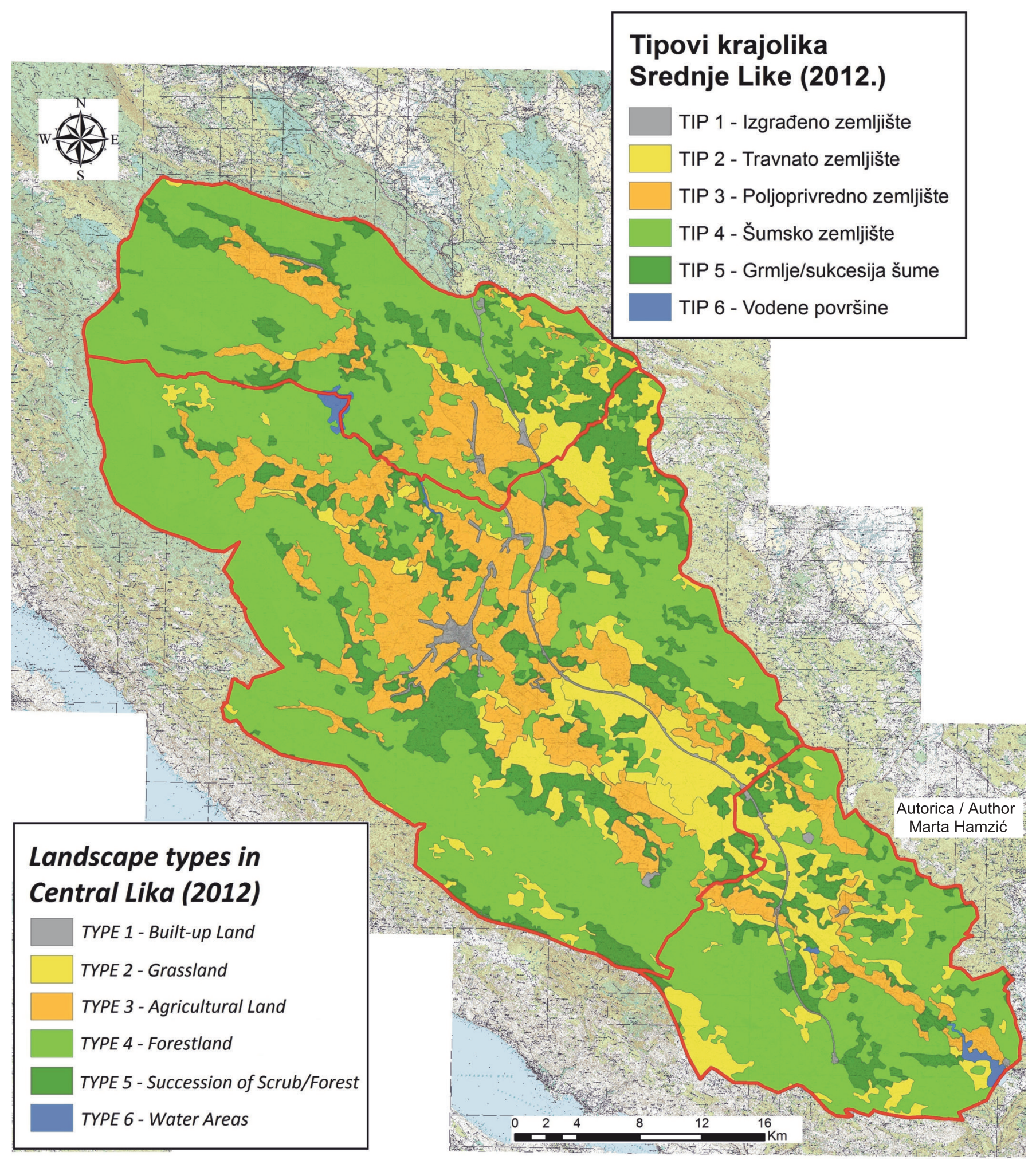

Slika 2. Tipovi krajolika Srednje Like (2012). Izvori: CLC 2012, HAOP; SRPJ, DGU; Topografske karte, DGU.

Fig. 2 Landscape types in Central Lika (2012). Source: CLC 2012, HAOP; SRPJ, SGA; Topographical maps, SGA. 
HAMZIĆ, M. ET AL.: STRUCTURAL CHARACTERISTICS OF PATCHES IN THE CENTRAL LIKA LANDSCAPE - APPLICATION OF SPATIAL AND REGRESSION ANALYSIS

Table 1 Results for the observed indicators of shape, position, and condition of landscape patches in Central Lika (2012).

Tablica 1. Rezultati promatranih pokazatelja za oblik, položaji stanje uzoraka krajolika Srednje Like (2012. godina).

\begin{tabular}{|c|c|c|c|c|c|c|c|c|}
\hline \multirow{2}{*}{\multicolumn{2}{|c|}{$\begin{array}{c}\text { OBILJEŽJA UZORAKA/ } \\
\text { Naziv metode/ Naziv parametra } \\
\text { CHARACTERISTICS OF PATCHES/ } \\
\text { Method name/ Parameter name }\end{array}$}} & \multicolumn{7}{|c|}{$\begin{array}{l}\text { TIP KRAJOLIKA } \\
\text { LANDSCAPE TYPE }\end{array}$} \\
\hline & & \begin{tabular}{|c} 
TIP 1 1 \\
Izgrađeno \\
zemljište \\
TYPE 1 \\
Built-up \\
Land
\end{tabular} & $\begin{array}{c}\text { TIP 2 } \\
\text { Travnato } \\
\text { zemljište } \\
\text { TYPE 2 } \\
\text { Grassland }\end{array}$ & $\begin{array}{c}\text { TIP } 3 \\
\text { Poljoprivredno } \\
\text { zemljište } \\
\text { TYPE } 3 \\
\text { Agricultural } \\
\text { Land }\end{array}$ & \begin{tabular}{|c} 
TIP 4 \\
Šumsko \\
zemljište \\
TYPE 4 \\
Forestland
\end{tabular} & $\begin{array}{l}\text { TIP } 5 \\
\text { Grmlje/ } \\
\text { sukcesija } \\
\text { šume } \\
\text { TYPE } 5 \\
\text { Succession } \\
\text { of Scrub/ } \\
\text { Forests }\end{array}$ & $\begin{array}{l}\text { TIP } 6 \\
\text { Vodene } \\
\text { površine } \\
\text { TYPE } 6 \\
\text { Water } \\
\text { Areas }\end{array}$ & $\begin{array}{l}\text { SREDNJA } \\
\text { LIKA } \\
\text { UKUPNO } \\
\text { CENTRAL } \\
\text { LIKA } \\
\text { SUM }\end{array}$ \\
\hline & $\begin{array}{l}\text { OBLIK UZORAKA } \\
\text { SHAPE OF PATCHES }\end{array}$ & & & & & & & \\
\hline \multirow{5}{*}{$\begin{array}{l}\text { Shape } \\
\text { Index }\end{array}$} & $\begin{array}{l}\text { Minimalni indeks oblika } \\
\text { Min. Shape Indeks }\end{array}$ & $\begin{array}{l}1,56 \\
1.56\end{array}$ & $\begin{array}{l}1,63 \\
1.63\end{array}$ & $\begin{array}{l}1,55 \\
1.55\end{array}$ & $\begin{array}{l}0,00 \\
0.00\end{array}$ & $\begin{array}{l}1,54 \\
1.54\end{array}$ & $\begin{array}{l}2,05 \\
2.05\end{array}$ & $\begin{array}{l}0,00 \\
0.00\end{array}$ \\
\hline & $\begin{array}{l}\text { Maksimalni indeks oblika } \\
\text { Max. Shape Index }\end{array}$ & $\begin{array}{l}16,89 \\
16.89\end{array}$ & $\begin{array}{l}5,58 \\
5.58\end{array}$ & $\begin{array}{l}6,66 \\
6.66\end{array}$ & $\begin{array}{l}14,4 \\
14.4\end{array}$ & $\begin{array}{l}7,66 \\
7.66\end{array}$ & $\begin{array}{l}6,82 \\
6.82\end{array}$ & $\begin{array}{l}16,89 \\
16.89\end{array}$ \\
\hline & $\begin{array}{l}\text { Prosječni indeks oblika } \\
\text { Mean Shape Index, MSI }\end{array}$ & $\begin{array}{l}4,19 \\
4.19\end{array}$ & $\begin{array}{l}2,66 \\
2.66\end{array}$ & $\begin{array}{l}2,75 \\
2.75\end{array}$ & $\begin{array}{l}2,56 \\
2.56\end{array}$ & $\begin{array}{l}2,76 \\
2.76\end{array}$ & $\begin{array}{l}3,96 \\
3.96\end{array}$ & $\begin{array}{l}2,74 \\
2.74\end{array}$ \\
\hline & $\begin{array}{l}\text { Opis oblika uzoraka } \\
\text { Description of patch shape }\end{array}$ & $\begin{array}{l}\text { Složeniji } \\
\text { More } \\
\text { complex }\end{array}$ & $\begin{array}{l}\text { Složen } \\
\text { Complex }\end{array}$ & $\begin{array}{l}\text { Složen } \\
\text { Complex }\end{array}$ & $\begin{array}{l}\text { Složen } \\
\text { Complex }\end{array}$ & $\begin{array}{l}\text { Složen } \\
\text { Complex }\end{array}$ & $\begin{array}{l}\text { Složen } \\
\text { Complex }\end{array}$ & $\begin{array}{l}\text { Složen } \\
\text { Complex }\end{array}$ \\
\hline & $\begin{array}{l}\text { POLOŽAJ UZORAKA } \\
\text { POSITION OF PATCHES }\end{array}$ & & & & & & & \\
\hline \multirow{9}{*}{$\begin{array}{c}\text { Average } \\
\text { Nearest } \\
\text { Neighbour }\end{array}$} & $\begin{array}{l}\text { Uočena srednja vrijednost } \\
\text { Observed Mean Distance }\end{array}$ & $\begin{array}{l}5675,23 \\
5675.23\end{array}$ & $\begin{array}{l}2365,68 \\
2365.68\end{array}$ & $\begin{array}{l}1411,42 \\
1411.42\end{array}$ & $\begin{array}{l}1897,85 \\
1897.85\end{array}$ & $\begin{array}{l}1908,84 \\
1908.84\end{array}$ & $\begin{array}{l}9799,76 \\
9799.76\end{array}$ & $\begin{array}{l}1032,07 \\
1032.07\end{array}$ \\
\hline & $\begin{array}{l}\text { Očekivana srednja vrijednost } \\
\text { Expected Mean Distance }\end{array}$ & $\begin{array}{l}4258,39 \\
4258,39\end{array}$ & $\begin{array}{l}2536,38 \\
2536.38\end{array}$ & $\begin{array}{l}1907,75 \\
1907.75\end{array}$ & $\begin{array}{l}2191,67 \\
2191.67\end{array}$ & $\begin{array}{l}1947,54 \\
1947.54\end{array}$ & $\begin{array}{l}3284,81 \\
3284.81\end{array}$ & $\begin{array}{l}1114,74 \\
1114.74\end{array}$ \\
\hline & $\begin{array}{l}\text { Omjer najbliže udaljenosti } \\
\text { Nearest Neighbour Ratio }\end{array}$ & $\begin{array}{l}1,33 \\
1.33\end{array}$ & $\begin{array}{l}0,93 \\
0.93\end{array}$ & $\begin{array}{l}0,74 \\
0.74\end{array}$ & $\begin{array}{l}0,87 \\
0.87\end{array}$ & $\begin{array}{l}0,98 \\
0.98\end{array}$ & $\begin{array}{l}2,98 \\
2.98\end{array}$ & $\begin{array}{l}0,93 \\
0.93\end{array}$ \\
\hline & $\begin{array}{l}\text { z-vrijednost } \\
\text { z-value }\end{array}$ & $\begin{array}{l}2,62 \\
2.62\end{array}$ & $\begin{array}{l}-1,28 \\
-1.28\end{array}$ & $\begin{array}{l}-5,63 \\
-5.63\end{array}$ & $\begin{array}{l}-2,89 \\
-2.89\end{array}$ & $\begin{array}{l}-0,46 \\
-0.46\end{array}$ & $\begin{array}{l}7,59 \\
7.59\end{array}$ & $\begin{array}{l}-3,25 \\
-3.25\end{array}$ \\
\hline & $\begin{array}{l}p \text {-vrijednost } \\
\text { p-value }\end{array}$ & $\begin{array}{l}0,0087 \\
0.0087\end{array}$ & $\begin{array}{l}0,2001 \\
0.2001\end{array}$ & $\begin{array}{l}0,0000 \\
0.0000\end{array}$ & $\begin{array}{l}0,0038 \\
0.0038\end{array}$ & $\begin{array}{l}0,6427 \\
0.6427\end{array}$ & $\begin{array}{l}0,0000 \\
0.0000\end{array}$ & $\begin{array}{l}0,0012 \\
0.0012\end{array}$ \\
\hline & $\begin{array}{l}\text { Opis položaja uzoraka } \\
\text { Description of patch position }\end{array}$ & $\begin{array}{l}\text { Raspršeno } \\
\text { Dispersed }\end{array}$ & $\begin{array}{c}\text { Nasumično } \\
\text { Random }\end{array}$ & $\begin{array}{l}\text { Grupirano } \\
\text { Clustered }\end{array}$ & $\begin{array}{l}\text { Grupirano } \\
\text { Clustered }\end{array}$ & $\begin{array}{c}\text { Nasumično } \\
\text { Random }\end{array}$ & $\begin{array}{l}\text { Raspršeno } \\
\text { Dispersed }\end{array}$ & $\begin{array}{l}\text { Grupirano } \\
\text { Clustered }\end{array}$ \\
\hline & $\begin{array}{c}\text { STANJE UZORAKA } \\
\text { CONDITION OF PATCHES }\end{array}$ & & & & & & & \\
\hline & $\begin{array}{l}\text { Broj uzoraka } \\
\text { Number of patches }\end{array}$ & 17 & 99 & 128 & 127 & 149 & 4 & 524 \\
\hline & $\begin{array}{l}\text { Površina }\left(\mathrm{km}^{2}\right) \\
\text { Surface area }\left(\mathrm{km}^{2}\right)\end{array}$ & $\begin{array}{l}21,77 \\
21.77\end{array}$ & $\begin{array}{l}203,18 \\
203.18\end{array}$ & $\begin{array}{l}266,42 \\
266.42\end{array}$ & $\begin{array}{l}932,47 \\
932.47\end{array}$ & $\begin{array}{l}258,16 \\
258.16\end{array}$ & $\begin{array}{l}7,90 \\
7.90\end{array}$ & $\begin{array}{l}1689,90 \\
1689.90\end{array}$ \\
\hline \multirow{2}{*}{$\begin{array}{l}\text { Core } \\
\text { Area }\end{array}$} & $\begin{array}{l}\text { Površina jezgre } \\
\text { Core Area }\left(\mathrm{km}^{2}\right)\end{array}$ & $\begin{array}{l}9,56 \\
9.56\end{array}$ & $\begin{array}{l}160,77 \\
160.77\end{array}$ & $\begin{array}{l}206,87 \\
206.87\end{array}$ & $\begin{array}{l}827,07 \\
827.07\end{array}$ & $\begin{array}{l}195,45 \\
195.45\end{array}$ & $\begin{array}{l}5,32 \\
5.32\end{array}$ & $\begin{array}{l}1405,04 \\
1405.04\end{array}$ \\
\hline & $\begin{array}{l}\text { Indeks površine jezgre } \\
\text { Core Area Index, CAI (\%) }\end{array}$ & $\begin{array}{l}43,91 \\
43.91\end{array}$ & $\begin{array}{l}79,13 \\
79.13\end{array}$ & $\begin{array}{l}77,65 \\
77.65\end{array}$ & $\begin{array}{l}88,70 \\
88.70\end{array}$ & $\begin{array}{l}75,71 \\
75.71\end{array}$ & $\begin{array}{l}67,34 \\
67.34\end{array}$ & $\begin{array}{l}83,14 \\
83.14\end{array}$ \\
\hline
\end{tabular}

the simplest, meaning it is closest to the shape of a circle. However, given this value, the shape of the patches in this landscape type can be described as complex. The CAI value is among the highest
(79.13\%) compared to other types of landscape in Central Lika. This means that in this landscape type, the surface area of the core of the patches among the largest, because only a small number of patches have a KiG No. 34, Vol. 19, 2020, https://doi.org/10.32909/kg.19.34.2 — 
nalaze na područjima podalje od naselja, jer se uz naselja nalaze ratarske površine. Prirodni travnjaci nalaze se na planinskim obroncima, ali i u nizinskom području (u Ličkom polju sa zapadne strane autoceste). Vrijednost MSI je među ostalim tipovima krajolika među najmanjima $(2,66)$, jer je kod tog tipa krajolika prosječan oblik uzorka jedan od najjednostavnijih, tj. sličniji je obliku kružnice. Ipak, s obzirom na tu vrijednost, oblik uzoraka tog tipa krajolika može se opisati kao složen. Vrijednost CAI je jedna od najvećih $(79,13 \%)$ među ostalim tipovima krajolika Srednje Like. To znači da je unutar tog tipa krajolika površina jezgre uzoraka jedna od najvećih, jer je mali broj uzoraka sa složenim ili izduženim oblikom. S obzirom na položaj uzoraka tog tipa krajolika, riječ je o nasumičnom položaju uzoraka. Time se zbog prosječne udaljenost među središtima susjednih uzoraka ne može reći da su ti uzorci grupirani, ali niti raspršeni. Međutim, p-vrijednost iznosi 0,2001 te je veća od granične vrijednosti $(0,05)$ što znači da se ti rezultati ne razlikuju od slučajnih i time se ne analiziraju u radu.

Tip krajolika Poljoprivredno zemljište sastoji se od ukupno 128 uzoraka. Položeni su bliže središnjem dijelu Srednje Like, dok su slabije zastupljeni na rubnom dijelu. Nalaze se uz naselja, jer su se ona razvila uz plodnija tla. Malobrojno stanovništvo iskorištava ga u poljoprivredne svrhe - uzgajaju se različite vrste kultura voća, povrća, žitarica te krmnog i stočnog bilja. Ukoliko se na području Srednje Like nastave prisutni društveno-gospodarski procesi (deagrarizacija, deruralizacija, urbanizacija, smanjenje ukupnog broja stanovnika, starenje stanovništva), izgledno je kako će sve manje površina biti pod kulturama koje su radno intenzivne (voće, povrće), a sve više površina će biti pod kulturama koje nisu radno intenzivne (žitarice, krmno i stočno bilje), ali i pod ugarom. Time će krajolik postajati sve zapušteniji, odnosno zeleniji. Jedino je na području bliže gradu Gospiću izgledno održavanje postojećeg obima poljoprivrednih površina.

Vrijednost MSI za tip krajolika Poljoprivredno zemljište iznosi 2,75. S obzirom na to da je ta vrijednost približno jednaka vrijednosti MSI za krajolik Srednje Like u cjelini $(2,74)$, može se reći kako im je oblik približno jednake složenosti kao i prosječan oblik svih uzoraka Srednje Like. S obzirom na tu vrijednost, oblik uzoraka tog tipa krajolika može se opisati kao složen. Vrijednost CAI je među najvišima (77,65 \%), jer je površina jezgre uzoraka veća zbog većeg broja uzoraka s jednostavnijim oblikom, odnosno mali je broj uzoraka sa složenim ili izduženim oblikom. Promatrajući položaj uzoraka tipa krajolika Poljoprivredno zemljište, riječ je o grupiranom položaju uzoraka. To znači da kod tog tipa krajolika nije velika prosječna udaljenost središta uzorka do središta susjednog uzorka, tj. da je poljoprivredno zemljište na području Srednje Like okupljeno.

Tip krajolika Šumsko zemlijšte sastoji se od ukupno 127 uzoraka. Uglavnom se nalaze na rubnim dijelovima područja istraživanja - na padinama Velebita, Ličkog sredogorja i Resnika, te rubnim dijelovima Ličkog polja i Lovinačkog polja. U Ličkom polju na nižim nadmorskim visinama pretežno se nalaze bjelogorične šume hrasta kitnjaka s običnim grabom (Querco petraeae-Carpinetum illyricum). Uz vodotoke su zastupljene manje površine pod šumama hidrofilnih vrsta crne johe sa šašom (Carici brizoidis-Alnetum), sive vrbe (Salix cinerea) i rakite (Salix purpurea). Na višim nadmorskim visinama iznad brdskih bukovih šuma (Fagetum illyricum montanum) na području srednjeg i sjevernog Velebita nastavljaju se šume bukve i jele (Abieti-Fagetum illyricum), a u najvišim dijelovima pretplaninske šume bukve (Fagetum illyricum subalpinum) (Pelcer i Martinović 2003).

Vrijednost MSI za taj tip krajolika je najmanja $(2,56)$ među ostalim promatranim tipovima krajolika. Dakle, uzorci koji se odnose na šumsko zemljište su najjednostavniji, tj. najviše sliče obliku kružnice. S obzirom na tu vrijednost, oblik uzoraka može se opisati kao složen. Vrijednost CAI za taj tip krajolika je najveća (88,70 \%) među ostalim tipovima krajolika Srednje Like. Naime, površina jezgre uzoraka je najveća, jer je među ostalim tipovima krajolika Srednje Like najveći broj uzoraka s jednostavnijim oblikom. S obzirom na položaj uzoraka tog tipa krajolika, riječ je o grupiranom položaju uzoraka, jer kod tipa krajolika Šumsko zemliššte prosječno nije velika udaljenost među središtima susjednih uzoraka.

Tip krajolika Grmlje/sukcesija šume uglavnom se nalazi u Ličkom polju i na najnižim padinama reljefnog okvira. Grmlje, odnosno sukcesija šume uglavnom se nalazi udaljeno od naselja, u pojasu između travnatog zemljišta i bjelogoričnih šuma. Pretežno su nastali zapuštanjem i napuštanjem poljoprivrednog zemljišta pa se može zaključiti kako je riječ o drugoj fazi sukcesije vegetacije. Obilježavaju ih različite vrste srednje visokog raslinja. Ukoliko su na tlima koja su obogaćena mineralnim sastojcima i nastave se prisutni društvenogospodarski procesi, postupno će prerastati u šume. Međutim, na pojedinim područjima se zbog slabije kvalitete tla (osiromašena su mineralnim sastojcima) ne može razviti treća faza sukcesija vegetacije, tj. tijekom vremena se iz grmlja ne razvija visoko raslinje (šuma). Na takvoj podlozi se kao sekundarna vegetacija razvijaju vrištine i bujadnice (paprati) (Genisto-Callunetum illyricum) (Pelcer i Martinović 2003).

Tip krajolika Grmlje/sukcesija šume sastoji se od najviše uzoraka - ukupno 149. Vrijednost MSI za taj tip krajolika jedna je od većih $(2,76)$, jer su oblici 
complex or elongated shape. The patches in this landscape type are randomly positioned. Hence, due to the average distance between the centres of neighbouring patches, they cannot be said to be either clustered or dispersed. However, the $p$-value is 0.2001 , which is higher than the borderline value (0.05), which means that these results do not differ from random ones and are therefore not analysed in the paper.

The landscape type Agricultural Land comprises a total of 128 patches. They are located close to the central part of Central Lika, and are less represented on the margins. They are located next to settlements and have developed on more fertile soil. The small population uses them for agricultural purposes, growing different crops, fruit, vegetables, cereals, fodder, and cattle-feed. If socio-economic processes continue in the area of Central Lika (deagrarisation, deruralisation, urbanisation, reduction of the total population, ageing of the population), it is likely that fewer and fewer areas will be used to cultivate labour-intensive crops (fruit and vegetables), and more areas will be used for non-labour-intensive crops (cereals, fodder and cattle-feed), or left fallow. The landscape will be more neglected, but greener. Only in the area close to the town of Gospić is it possible to maintain the current extent of agricultural land.

The MSI value for the landscape type Agricultural Land is 2.75 . Given that this value is approximately equal to the MSI value for the Central Lika landscape as a whole (2.74), it can be said that the patch shape is approximately as complex as the average shape of all Central Lika patches. According to this value, the shape of the patches in this landscape type can be described as complex. The CAI value is among the highest (77.65\%), because the surface area of the patch core is larger, due to the large number of patches with a simpler shape and the small number of patches with a complex or elongated shape. The patches for the landscape type Agricultural Land are in a clustered position. This means that in this landscape type, the average distance from the centre of one patch to the centre of the next neighbouring patch is not great. In other words, the agricultural plots in Central Lika are arranged close together.

The landscape type Forestland comprises a total of 127 patches. They are mainly located on the margins of the research area - on the slopes of Velebit, the Lika highlands and Resnik, and on the margins of Ličko polje (Lika field) and Lovinačko polje (Lovinac field). In Ličko polje, there are mostly deciduous forests of sessile oak with common hornbeam (Querco petraeae-Carpinetum Illyricum) at lower altitudes.
Along the water courses, there are smaller areas beneath the forests of hydrophilic species of black alder with sedge (Carici brizoidis-Alnetum), grey willow (Salix cinerea) and willow (Salix purpurea). At higher altitudes above the mountain beech forests (Fagetum illyricum montanum) in the area of central and northern Velebit, there are beech and fir forests (Abieti-Fagetum illyricum), and in the highest parts of the mountain forests beneath the peaks, sub-alpine beech forests grow (Fagetum illyricum subalpinum) (Pelcer and Martinović 2003).

The MSI value for this landscape type is the lowest (2.56) compared to other observed landscape types. Thus, the patches related to forest land are the simplest, that is, closest to the shape of a circle. Given this value, the shape of the patches can be described as complex. The CAI value for this landscape type is the highest (88.70\%) compared to other types of landscape in Central Lika. The core area of the patches is the largest, because the highest number of patches have a simpler shape. The patches in this landscape type are clustered, because on average there is a smaller distance between the centres of neighbouring patches.

The landscape type Succession of Scrub/Forests is mainly located in Ličko polje and on the lowest slopes of the relief frame. Shrubs, that is, forest succession, are mostly located far from settlements, in the belt between grassland and deciduous forests. They are mostly created when agricultural land is abandoned or neglected, and represent the second phase of vegetation succession. This landscape type is characterised by different species of medium-high vegetation. If these grow in areas where socio-economic processes have enriched the soil with mineral ingredients, they will gradually grow into forests. However, in some areas, due to the poorer quality of the depleted soil, the third phase of vegetation succession will not develop, and no tall vegetation (forests) will develop from the shrubs. On such substrates, heathers and ferns (Genisto-Callunetum illyricum) develop as secondary vegetation (Pelcer and Martinović 2003).

The landscape type Succession of Scrub/Forests comprises the highest number of patches - a total of 149. The MSI value for this landscape type is one of the highest (2.76), because the shapes of patches related to shrubs/forest succession is among the most complex compared to other observed landscape types. The CAI value is one of the lowest (75.71\%), because the surface area of the patch core is one of the smallest due to fewer patches with a simpler shape, and more patches with a more complex

KiG No. 34, Vol. 19, 2020, https://doi.org/10.32909/kg.19.34.2 - - 
uzoraka koji se odnose na grmlje, odnosno sukcesiju šume jedni od najsloženijih među ostalim promatranim tipovima krajolika, pa se mogu opisati kao složeni. Vrijednost CAI je jedna od najmanjih (75,71\%), jer je površina jezgre uzoraka jedna od najmanjih zbog manjeg broja uzoraka s jednostavnijim oblikom, odnosno većeg broja uzoraka sa složenijim oblikom. Ipak, s obzirom na vrijednost MSI, prosječan oblik uzorka tog tipa krajolika približno je jednake složenosti kao i prosječan uzorak krajolika Srednje Like u cjelini $(2,74)$. Promatrajući položaj uzoraka tipa krajolika Grmlje/sukcesija šume, riječ je o nasumičnom položaju uzoraka. Međutim, $p$-vrijednost iznosi 0,6427 i veća je od granične vrijednosti $(0,05)$ što znači da se ti rezultati ne razlikuju od slučajnih i time se ne analiziraju u radu.

Tip krajolika Vodene površine na području Srednje Like odnosi se na nekoliko objekata: jedan vodotok (donji dio toka ponornice Lika) i tri vodna tijela (Kruščićko jezero, jezero štikada s jezerom Ričice te retencija na ponornici Obsenica). Naime, iako je zbog prirodnih preduvjeta, područje Srednje Like bogato vodom (brojna vrela i izvori te veliki broj manjih ili većih vrela, izvora, vodotoka i vodnih tijela), korišteni podatci ukazuju na to da tipu krajolika Vodene površine pripada tek nekoliko objekata, što je razumljivo jer su površinom vrlo mali. Time se tip krajolika Vodene površine sastoji od najmanje uzoraka - ukupno četiri. Vrijednost MSI za taj tip krajolika je jedna od većih $(3,96)$, pa se prosječan oblik uzorka tog tipa krajolika može opisati kao složen. Vrijednost CAI je jedna od najmanjih $(67,34 \%)$ među ostalim promatranim tipovima krajolika, jer je površina jezgre uzoraka jedna od najmanjih zbog manjeg broja uzoraka s jednostavnijim oblikom, odnosno većeg broja uzoraka sa složenijim oblikom. Štoviše, uzorci tipa krajolika Vodene površine, uz uzorke tipa krajolika Izgrađeno zemljište, imaju najsloženiji oblik. Promatrajući položaj uzoraka tipa krajolika Vodene površine, riječ je o raspršenom položaju uzoraka. To znači da je prosječno velika udaljenost među središtima susjednih uzoraka ovog tipa krajolika.

\section{Regresijska analiza odabranih vrijednosti strukturnih obilježja uzoraka krajolika Srednje Like}

U linearno-regresijskoj analizi koriste se pojedine vrijednosti obilježja uzoraka krajolika Srednje Like. Te vrijednosti su dobivene kao rezultat primjene različitih metoda na uzorcima krajolika Srednje Like za tipove krajolika i krajolik Srednje Like u cjelini. $\mathrm{Na}$ temelju rezultata linearno-regresijske analize podrobnije se objašnjavaju međuodnosi u radu korištenih pokazatelja za oblik, položaj i stanje uzoraka krajolika Srednje Like. Linearna regresija provedena je s pomoću programa IBM SPSS Statistics verzije 20 .

Model jednostavne linearne regresije izražava se pomoću sljedeće jednadžbe (Corporate Finance Institute 2020):

$\mathrm{Y}=\mathrm{a}+\mathrm{bX}+\epsilon$

$\mathrm{Y}$ - zavisna varijabla

$\mathrm{X}$ - nezavisna varijabla

$a, b$ - parametri

$\epsilon$-odstupanje

Analiziran je odnos pokazatelja MSI - prosječne vrijednosti indeksa oblika (vrijednost za oblik uzoraka krajolika) te CAI - indeksa površine jezgre (vrijednost za stanje uzoraka krajolika) (slika 3).

Linearno-regresijskom analizom navedenih pokazatelja dobivena je vrijednost standardiziranog koeficijenta $\beta(\beta=-0,899)$ koja ukazuje na jaku vezu negativnog smjera. Pri tome je dobivena $p$-vrijednost $(p=$ $0,006)$ koja označava da se promatrana pojava razlikuje od slučajne. To znači da s porastom indeksa oblika (MSI), površina jezgre se smanjuje, i obratno. Time se može zaključiti kako uzorci složenijeg oblika imaju manju površinu jezgre. $S$ druge strane, što je uzorcima oblik jednostavniji (više nalikuje obliku kružnice), to će površina jezgre biti veća. Navedeno je vidljivo i u rezultatima prikazanim u prošlom poglavlju. Tako na primjer, tip krajolika Izgrađeno zemljište ima najveću vrijednost pokazatelja MSI, a najmanju vrijednost pokazatelja CAI, jer je kod tog tipa krajolika najveći broj uzoraka sa složenim ili izduženim oblikom zbog čega je i površina jezgre uzoraka najmanja. $S$ druge strane, tip krajolika Šumsko zemljište ima najmanju vrijednost pokazatelja MSI, a najveću pokazatelja CAI. Time je ukazano kako je kod tog tipa krajolika najveći broj uzoraka s jednostavnijim oblikom zbog čega je i površinu jezgre uzoraka najveća. Dobivena vrijednost koeficijenta determinacije $\left(\mathrm{R}^{2}=0,809\right)$ ukazuje kako je 80,9 \% veze objašnjeno ispitanom korelacijom.

Analiziran je zatim odnos pokazatelja MSI - prosječne vrijednosti indeksa oblika (vrijednost za oblik uzoraka krajolika) i od metode Average Nearest Neighbour, vrijednosti Observed Mean Distance - uočene srednje vrijednosti susjednosti (vrijednost za položaj uzoraka krajolika) (slika 4).

Regresijskom analizom dobivena je vrijednost standardiziranog koeficijenta $\beta(\beta=0,864)$ koja ukazuje na jaku vezu, pozitivnog smjera. Pri tome je dobivena $p$-vrijednost $(p=0,001)$ koja označava da se 
shape. Nevertheless, given the MSI value, the average patch shape for this landscape type is about as complex as the average patch in the Central Lika landscape (2.74). The patches in the landscape type Succession of Scrub/Forests are positioned randomly. However, the $p$-value is 0.6427 and is higher than the borderline value (0.05), which means that these results do not differ from random ones and are therefore not analysed in the paper.

The landscape type Water Areas in Central Lika refers to several objects: one watercourse (the lower course of the River Lika, which also flows underground) and three bodies of water (Lake Kruščićko, Lake Štikada with Lake Ričice and the retainer on the subterranean River Obsenica). Even though, due to natural conditions, the area of Central Lika is abundant in water (numerous springs and sources, watercourses, and bodies of water), the data indicate that only a few objects belong to the landscape type Water Areas which is understandable because they are very small in area. Thus, this landscape type comprises the fewest patches - a total of four. The MSI value for this landscape type is one of the highest (3.96), and the average patch shape of this landscape type can be described as complex. The CAI value is one of the lowest (67.34\%) compared to other observed landscape types, because the surface area of the patch core is one of the smallest due to the lower number of patches with simpler shapes and the higher number of patches with more complex shapes. Moreover, patches of landscape type Water Areas, along with patches of landscape type Built-up Area, have the most complex shapes. The position of the patches of landscape type Water Areas is dispersed. This means that on average, there is a long distance between the centres of neighbouring patches for this landscape type.

\section{Regression Analysis of Selected Values of Structural Characteristics of Landscape Types in Central Lika}

In the linear regression analysis, specific values were used for the characteristics of Central Lika's landscape. These values were obtained as a result of using GIS technology methods on landscape patches in Central Lika according to landscape types and the Central Lika landscape as a whole. Based on the results of the linear regression analysis, the interrelations are explained further according to the applied indicators used in the study for the shape, position and condition of the landscape patches in Central Lika. Linear regression was performed in IBM SPSS Statistics version 20.
The model of simple linear regression is expressed using the following equation (Corporate Finance Institute 2020):

$$
\begin{aligned}
& \mathrm{Y}=\mathrm{a}+\mathrm{bX}+\epsilon \\
& \mathrm{Y} \text { - dependent variable } \\
& \mathrm{X} \text { - independent variable } \\
& \mathrm{a}, \mathrm{b} \text { - parameters } \\
& \epsilon \text { - residual (error) }
\end{aligned}
$$

The relationship between the MSI indicator - the average value of the shape index (value for the shape of landscape patches) and the CAI - core area index (value for the condition of landscape patches) was analysed (Figure 3).

By conducting a regression analysis of these indicators, the value of the standardized coefficient $\beta$ $(\beta=-0.899)$ was obtained, which indicated a strong negatively oriented connection. A $p$-value $(p=0.006)$ was obtained, which indicated that the observed phenomenon differed from the random one. This meant that as the shape index (MSI) increased, the core area decreased, and vice versa. Thus, it can be concluded that patches with more complex shapes have a smaller core area. On the other hand, the simpler the shape of the patches (the closer to a circle), the larger the surface area of the core. This is also evident in the results presented in the previous chapter. So, for example, the landscape type Built-up Land has the highest MSI value and the lowest CAI value, because this landscape type has the largest number of patches with complex or elongated shapes, so the surface area of the patch core is the smallest. On the other hand, the landscape type Forestland has the lowest MSI value and the highest CAI value. This indicates that this landscape type has the highest number of patches with a simpler shape, which is why the surface area of the core of the patches is the largest. The obtained value of the determination coefficient $\left(R^{2}=0.809\right)$ indicates that $80.9 \%$ of the connections were explained by the examined correlation.

The relationship of the MSI indicator - the average value of the shape index (value for the shape of landscape patches) and, using the GIS method Average Nearest Neighbour, the values of the Observed Mean Distance - the observed mean value of the average nearest neighbour (value for the position of landscape patches) was analysed (Figure 4).

The linear regression analysis yielded a value for the standardized coefficient $\beta(\beta=0.864)$ indicating a strong, positively oriented connection. A $p$-value $(p=$ 0.001) was obtained which indicated that the observed

KiG No. 34, Vol. 19, 2020, https://doi.org/10.32909/kg.19.34.2 - - 
promatrana pojava razlikuje od slučajne. Dobiveni rezultat znači da s porastom indeksa oblika, susjednost uzoraka se povećava, i obratno. Time se može zaključiti kako uzorci složenijeg oblika imaju veću susjednost (udaljeniji su, odnosno raspršeni), a što im je oblik jednostavniji (više nalikuje obliku kružnice) susjednost će biti manja (bliži su, odnosno grupirani). Tako na primjer, tipovi krajolika Izgrađeno zemljište i Vodene površine imaju najveće vrijednosti pokazatelja MSI, ali i vrijednosti pokazatelja Average Nearest Neighbour - Observed Mean Distance. Naime, kod tih tipova krajolika najveći je broj uzoraka sa složenim ili izduženim oblikom, a s obzirom na veliku udaljenost središta uzoraka do središta susjednog uzoraka, položaj uzoraka je raspršen. S druge strane, tip krajolika Šumsko zemljište ima najmanju vrijednost pokazatelja MSI, jer je najveći broj uzoraka s jednostavnijim oblikom. S obzirom na malu udaljenost središta uzorka do središta susjednog uzorka, položaj uzoraka je grupiran. Dobiveni koeficijent determinacije $\left(\mathrm{R}^{2}=0,746\right)$ ukazuje kako je $74,6 \%$ veze objašnjeno ispitanom korelacijom.

Regresijskom analizom analiziran je i odnos pokazatelja CAI - indeksa površine jezgre (vrijednost za stanje uzoraka krajolika) te Average Nearest Neighbour - Observed Mean Distance - uočene srednje vrijednosti susjednosti (vrijednost za položaj uzoraka krajolika). Pri tome su dobivene vrijednosti koeficijenta determinacije $\left(R^{2}=0,363\right)$ i standardiziranog koeficijenta $\beta(\beta=-0,602)$. Međutim, dobivena $p$-vrijednost $(p=$ $0,152)$ veća je od granične vrijednosti $(0,05)$, što označava da se promatrana pojava ne razlikuje od slučajne, pa ovi rezultati nisu dalje analizirani.

Prethodno provedeno istraživanje M. Jovanić (2017) detaljnijeg uzorka krajolika i za podtipove i tipove krajolika te krajolik Srednje Like u cjelini potvrđuje ovdje prikazane rezultate za povezanost oblika i stanja $\left(\beta=-0,550 ; p=0,004 ; R^{2}=0,302\right)$ te oblika i položaja $\left(\beta=0,659 ; \mathrm{p}=0,001 ; \mathrm{R}^{2}=0,434\right)$ uzoraka krajolika Srednje Like, dok za stanje i položaj uzoraka krajolika Srednje Like također nije utvrđena povezanost. Time su potvrđeni međuodnosi korištenih pokazatelja za oblik, položaj i stanje uzoraka krajolika Srednje Like koji su prikazani u ovom radu.

\section{Zaključak}

Prikazano istraživanje odnosi se primjenu prostorne i linearno-regresijske analize $\mathrm{u}$ utvrđivanju strukturnih obilježja (oblik, položaj i stanje) uzoraka krajolika Srednje Like, odnosno njihovih međuodnosa za jednu vremensku točku (2012).

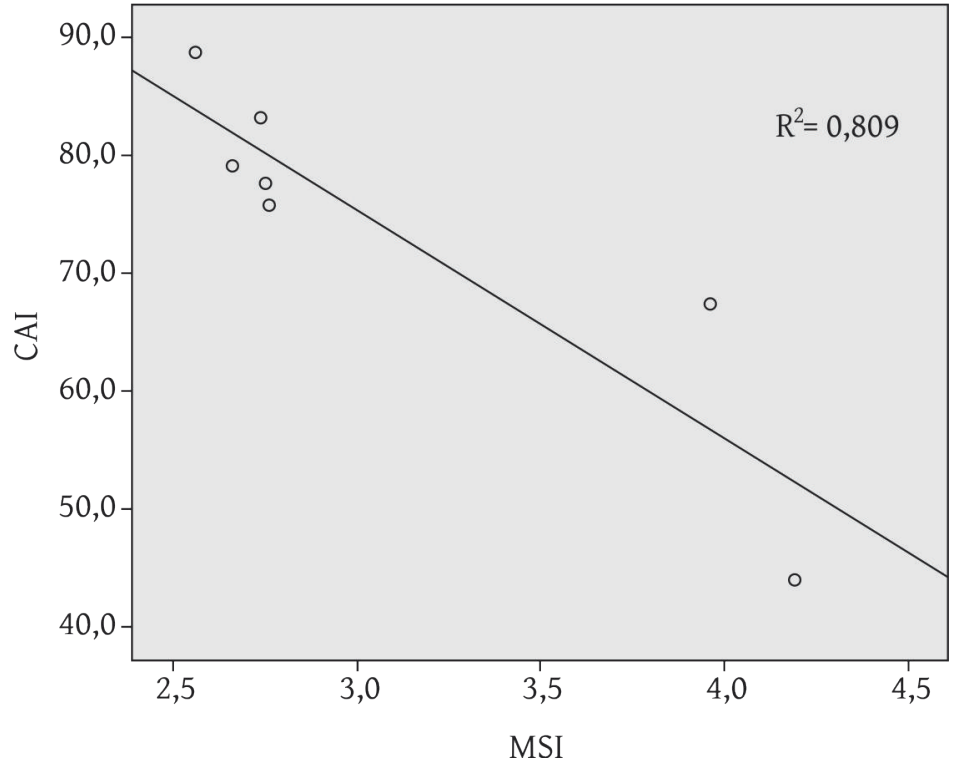

Slika 3. Dijagram raspršenosti odnosa prosječne vrijednosti indeksa oblika (MSI) i indeksa površine jezgre (CAI).

Fig 3. Scatter diagram showing the correlation of the average value of the shape index (MSI) and the core area index (CAI).

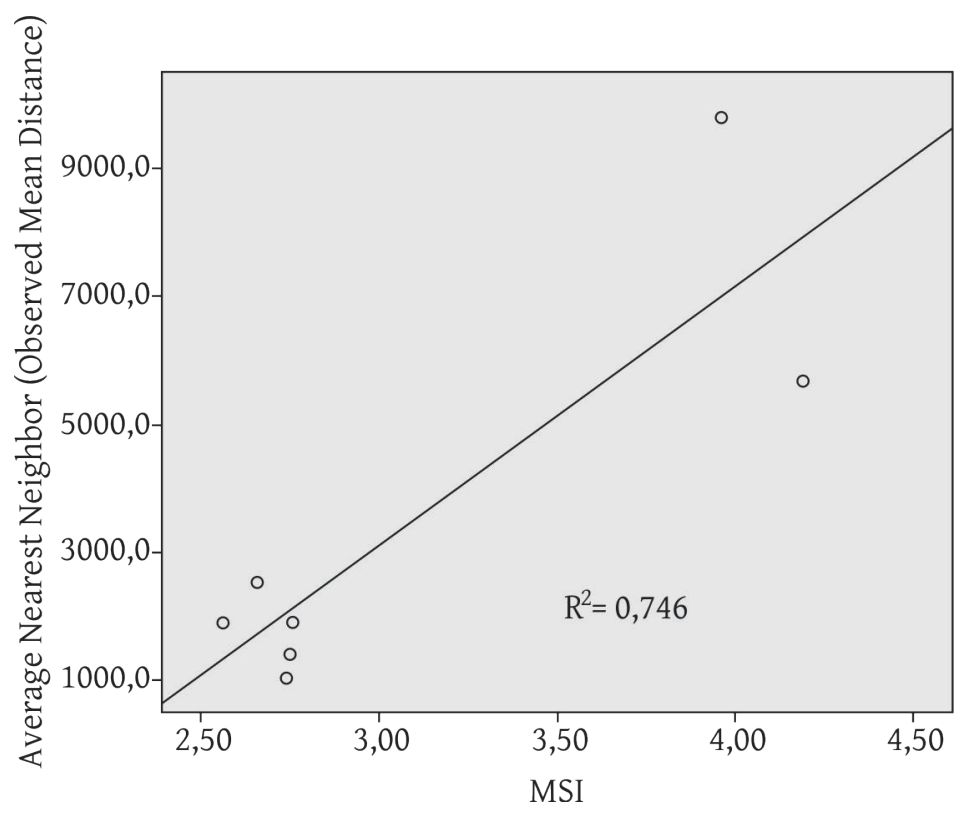

Slika 4. Dijagram raspršenosti odnosa prosječne vrijednosti indeksa oblika (MSI) i uočene srednje vrijednosti susjednosti (Average Nearest Neighbour - Observed Mean Distance).

Fig 4. Scatter diagram showing the correlation of the average value of the shape index (MSI) and the Average Nearest Neighbour - Observed Mean Distance.
U prostornoj analizi koristi se pristup u kojem se za tipove krajolika i krajolik Srednje Like primjenjuje skup pokazatelja za strukturu krajolika i GIS tehnologija, pri čemu se za svako od strukturnih obilježja koristi po jedna metoda prostorne analize. Pri 
phenomenon differed from the random one. The result obtained meant that with an increase in the shape index, the adjacency of the patches increased, and vice versa. Thus, it can be concluded that patches of a more complex shape have a more distant near neighbour connection (they are more distant or dispersed), and the simpler their shape (more like a circle) the closer they are clustered. For example, the landscape types Built-up Land and Water Area have the highest MSI indicator values, and also the Average Nearest Neighbour - Observed Mean Distance indicator values. In these landscape types, the largest number of patches have a complex or elongated shape. Also, given the long distance from the patch centre to the centre of the neighbouring patch, the position of the patches is dispersed. On the other hand, the landscape type Forestland has the lowest MSI indicator value, because it has the largest number of patches with a simpler shape. Given the small distance from the patch centre to the centre of the neighbouring patch, the patches are clustered. The obtained determination coefficient $\left(\mathrm{R}^{2}=0.746\right)$ indicates that $74.6 \%$ of the connection was explained by the examined correlation.

Regression analysis was also used to analyse the connection of the CAI - core area index (value for the condition of landscape patches) and the Average Nearest Neighbour - Observed Mean Distance (value for the position of landscape patches). The values of the determination coefficient $\left(R^{2}=0.363\right)$ and the standardized coefficient $\beta(\beta=-0.602)$ were obtained. However, the obtained $p$-value $(p=0.152)$ was higher than the borderline value (0.05), which meant that the observed phenomenon did not differ from the random one, so these results were not analysed further.

Previously conducted research by M. Jovanić (2017) on a more detailed sample, landscape patches for both subtypes and types of landscapes and the landscape of Central Lika as a whole, confirmed the results presented here for the correlation between shape and condition $\left(\beta=-0.550 ; p=0.004 ; R^{2}=0.302\right)$ as well as shape and position $\left(\Omega=0.659 ; p=0.001 ; R^{2}=\right.$ 0.434) of the Central Lika landscape patches, while also no correlation for the condition and position of the landscape patches of Central Lika was found.

\section{Conclusion}

The research presented relates to the application of spatial and linear regression analysis in determining the structural features (shape, position and condition) of patches in the Central Lika landscape, that is, their interrelation at one particular point in time (2012).
The spatial analysis in this paper uses an approach in which a set of indicators for landscape structure and GIS technologies was applied to landscape types and the Central Lika landscape, using a single spatial analysis method for each of the structural characteristics. To determine the landscape types, an approach based on land cover/land use was used. Six landscape types were identified in Central Lika and are analysed in detail in this paper.

Linear regression analysis established the connection between the shape and condition, and the shape and position of the patches in the landscape of Central Lika. However, no correlation was found for the condition and position of the patches in the Central Lika landscape. Thus, for shape and condition, the results showed that patches with a more complex shape had a smaller core area, that is, the simpler the shape of the patches (closer to a circle), the larger the surface area of the core. This was also evident in the results, where the landscape types Built-up Land and Forestland stood out. In fact, considering shape, the results showed that in Central Lika, patches of the landscape type Forestland had the simplest shape, that is, were closest to a circle, while landscape type patches of Built-up Land had the most complex shape, because this landscape type consists of patches with a complex shape (for example, settlements) or an elongated one (for example, highways and associated land). On the other hand, considering the condition of landscape patches, the results showed that in the landscape type Forestland the patch core area was the largest because, compared to other landscape types, a large number of patches had a simpler shape, while in the landscape type Builtup Land, the patch core area was the smallest because it had the largest number of patches with a complex or elongated shape. Based on the above, that is, the established link between shape and condition, it can be concluded that the patches of the landscape type Forestland are the least exposed to external influences, because they occupy the fewest marginal areas. On the other hand, patches in the Built-up Land landscape type occupy the most marginal areas and are exposed to the greatest external influences.

The results of the linear regression analysis for the shape and position of patches in the Central Lika landscape showed that patches with a more complex shape have a higher level of adjacency, and the simpler their shape (closer to a circle) the lower the adjacency. This is also evident in the results presented in the paper. Observing the landscape types that have the most complex patch shapes, Built-up Land and Water Areas, they also have the highest adjacency. Only

KiG No. 34, Vol. 19, 2020, https://doi.org/10.32909/kg.19.34.2 - - 
utvrđivanju tipova krajolika koristio se pristup koji se temelji na zemljišnom pokrovu/načinu korištenja zemljišta temeljem čega je utvrđeno šest tipova krajolika Srednje Like, koji su u radu detaljno analizirani.

$\mathrm{U}$ radu je linearno-regresijskom analizom ustanovljena povezanost za oblik i stanje, te za oblik i položaj uzoraka krajolika Srednje Like. Međutim, nije utvrđena povezanost za stanje i položaj uzoraka krajolika Srednje Like. Tako su za oblik i stanje rezultati pokazali kako uzorci složenijeg oblika imaju manju površinu jezgre, odnosno što je uzorcima oblik jednostavniji (više nalikuje obliku kružnice), to će površina jezgre biti veća. Navedeno je vidljivo i u rezultatima gdje se ističu tipovi krajolika Izgradeno zemljište i Šumsko zemljište. Naime, s obzirom na oblik rezultati su pokazali kako na području Srednje Like uzorci tipa krajolika Šumsko zemljište imaju najjednostavniji oblik, tj. najviše sliče obliku kružnice, dok uzorci tipa krajolika Izgrađeno zemljište imaju najsloženiji oblik, jer se taj tip krajolika sastoji od uzoraka sa složenim (npr. naselja), odnosno izduženim oblikom (npr. autocesta i pripadajuće zemljište). S druge strane, s obzirom na stanje uzoraka krajolika, rezultati su pokazali da je kod tipa krajolika Šumsko zemljište površina jezgre uzoraka najveća jer je među ostalim tipovima krajolika najveći broj uzoraka s jednostavnijim oblikom, dok je kod tipa krajolika Izgrađeno zemljište površina jezgre uzoraka najmanja jer je najveći broj uzoraka sa složenim ili izduženim oblikom. Na temelju navedenog, odnosno ustanovljene povezanosti za oblik i stanje, može se zaključiti i da su uzorci tipa krajolika Šumsko zemljište najmanje izloženi vanjskim utjecajima, jer imaju najmanje područje uzoraka pod rubnim dijelom. S druge strane, uzorci tipa krajolika Izgrađeno zemljište imaju najveći rubni dio te su pod najvećim vanjskim utjecajima.

Rezultati linearno-regresijske analize za oblik i položaj uzoraka krajolika Srednje Like pokazali su da uzorci složenijeg oblika imaju veću susjednost, a što im je oblik jednostavniji (više nalikuje obliku kružnice) susjednost će biti manja. To je vidljivo i u rezultatima prikazanim u radu rezultatima. Promatrajući tipove krajolika koji imaju najsloženiji oblik uzoraka krajolika - Izgrađeno zemljište i Vodene površine, ujedno imaju i najveću susjednost, a samo kod tih tipova krajolika ustanovljeno je kako imaju raspršene uzorke, tj. prosječno je velika udaljenost središta uzorka do središta susjednog uzorka. S druge strane, tip krajolika Šumsko zemljište koji ima najjednostavniji oblik uzoraka krajolika, ujedno ima jednu od najmanjih susjednosti među ostalim tipovima krajolika Srednje Like. Također, za taj tip krajolika utvrđeno je kako ima grupirane uzorke, tj. nije velika prosječna udaljenost središta uzorka do središta susjednog uzorka.

U ovom istraživanju korišteni su podatci baze podataka CORINE Land Cover 2012, koja ne bilježi sve kategorije krajolika, što predstavlja izvjestan nedostatak te baze. Međutim, s druge strane njezina je značajna prednost što se izrađuje na europskoj razini prema prihvaćenoj CLC metodologiji, stoga je ovo istraživanje u potpunosti usporedivo $s$ drugim istraživanjima na području Europe u kojima bi se koristili pristupi i metode koji su prikazani $u$ ovom radu. Usporedivost rezultata u slučaju korištenja nekih drugih baza, primjerice multispektralnih satelitskih snimaka, bila bi značajno smanjena zbog velike različitosti u pristupima i metodologiji obrade kod različitih autora.

Primjenjivost saznanja o međuodnosima oblika, položaja i stanja uzoraka krajolika, koja ukazuju na (ne)prisutnost vanjskih utjecaja na njegov razvoj i promjene, prije svega je u prostornom planiranju različitih aktivnosti i područja/objekata odgovarajućih namjena. Posebice, međuodnosi oblika i položaja uzoraka krajolika mogu dati uvid u najpogodniji odabir lokacije za zaštitne okolišne aktivnosti, primjerice kod aktivnosti vezanih za zaštitu ljudi, biljaka i životinja od negativnih vanjskih utjecaja (lociranje bukobrana, gnijezda, pojilišta, i sl.).

\section{Izvori podataka}

Baza podataka: Corine Land Cover 2012, HAOP, Zagreb.

Baza podataka: Digitalni atlas Republike Hrvatske, Državna geodetska uprava (DGU), Zagreb

Baza podataka: Središnji registar prostornih jedinica, Državna geodetska uprava (DGU), Zagreb

Topografska karta mjerila 1: 25000 (DGU), listovi: Bakovac Kosinjski 4515-4-3-2, Baške Oštarije 4515-4-34, Bunić 4516-3-3-1, Gornji Kosinj 4515-4-4-1, Gospić (Istok) 4515-4-4-4, Gospić (Zapad) 4515-4-4-3, Gračac 4416-1-2-3, Karlobag 4515-4-3-3, Krasno 4515-4-1-3, Krbava 4516-3-3-4, Lički Ribnik 4415-2-2-2, Ličko Lešće 4515-4-2-3, Lovinac 4416-1-1-2, Lukovo Šugarje 4415-21-2, Medak 4516-1-1-1, Ondić 4416-1-2-1, Otočac 45154-1-4, Perušić 4515-4-4-2, Rizvanuša 4515-2-2-1, Sveti Rok 4416-1-1-4, Štirovača 4515-4-3-1, Vaganski Vrh 4416-1-1-3, Vrhovine 4515-4-2-4, Velika Paklenica 4415-2-2-4, Vrebac 4516-3-3-3 
these landscape types were found to have dispersed patches, that is, the average distance from the centre of the patch to the centre of the neighbouring patch is long. On the other hand, the landscape type Forestland that has the simplest shape of landscape patches and the lowest adjacency of all the landscape types in Central Lika. Also, this landscape type was found to have clustered patches, that is, the average distance from the centre of one patch to the centre of its neighbour was not long.

Data from the CORINE Land Cover 2012 database were used in this paper. It does not record all landscape categories, which is a certain disadvantage of this database. However, on the other hand, its significant advantage is that it is made at the European level according to the accepted CLC methodology, so this research is completely comparable with other research in Europe that would use the approaches and methods presented in this paper. The comparability of the results in the case of using some other databases, such as multispectral satellite images, would be significantly reduced due to the large differences in approaches and processing methodologies among different authors.

The applicability of knowledge about the interrelationships of shapes, positions and conditions of landscape patches, which indicate the (non) presence of external influences on its development and changes, is primarily in the physical planning of various activities and areas / facilities of appropriate purposes. In particular, the interrelationships of the shape and position of landscape samples can provide insight into the most suitable site selection for protective environmental activities, for example in activities related to the protection of humans, plants and animals from negative external influences (locating noise barriers, nests, watering places, etc.).

\section{Data sources}

Database: Corine Land Cover 2012, HAOP, Zagreb.

Database: Digital atlas of the Republic of Croatia, State Geodetic Administration (SGA), Zagreb

Database: Central register of spatial units, State Geodetic Administration (SGA), Zagreb

Topographic map, scale 1: 25000 (SGA), sheets: Bakovac Kosinjski 4515-4-3-2, Baške Oštarije 4515-4-3-4, Bunić 4516-3-3-1, Gornji Kosinj 4515-4-4-1, Gospić (Istok) 45154-4-4, Gospić (Zapad) 4515-4-4-3, Gračac 4416-1-2-3, Karlobag 4515-4-3-3, Krasno 4515-4-1-3, Krbava 4516-3-3-4, Lički Ribnik 4415-2-2-2, Ličko Lešće 4515-4-2-3, Lovinac 4416-1-1-2, Lukovo Šugarje 4415-2-1-2, Medak 4516-1-11, Ondić 4416-1-2-1, Otočac 4515-4-1-4, Perušić 4515-4-42, Rizvanuša 4515-2-2-1, Sveti Rok 4416-1-1-4, Štirovača 4515-4-3-1, Vaganski Vrh 4416-1-1-3, Vrhovine 4515-4-24, Velika Paklenica 4415-2-2-4, Vrebac 4516-3-3-3

\section{References / Literatura}

Antrop M (2005) Why landscapes of the past are important for the future. Landscape and Urban Planning, vol. 70, no. 1-2, 21-34. doi: 10.1016/j.landurbplan.2003.10.002

Aničić B, Perica D (2003) Structural features of cultural landscape in the carst area (landscape in transition). Acta carsologica, vol. 32, no. 1, 173-188. doi: 10.3986/ac.v32i1.372

Blaschke T (2000) Vernetzung von Landschaftselementen: Die Rolle von GIS in der Landschaftsplanung. GIS - Zeitschrift für GeoInformationssysteme, vol. 6,17-26

Blaće A (2015) Razvoj i suvremena preobrazba krajolika Ravnih kotara. Doktorski rad, Sveučilište u Zagrebu, Prirodoslovnomatematički fakultet, Geografski odsjek, Zagreb

Blaće A (2019) Promjene šumskoga pokrova na području Ravnih kotara u drugoj polovici 19. stoljeća. Hrvatski geografski glasnik, vol. 81, no. 2, 69-88. doi: 10.21861/HGG.2019.81.02.03

Cole B, Smith G, Balzter H (2018) Acceleration and fragmentation of Corine land cover changes in the United Kingdom from 20062012 detected by Copernicus IMAGE2012 satellite dana. Internal Journal of Applied Earth Observation and Geoinformation, vol. 73, 107-122. doi: 10.1016/j.jag.2018.06.003

Cvitanović M (2014) Promjene zemljišnog pokrova i načina korištenja zemljišta u Krapinsko-zagorskoj županiji od 1991. do 2011. Hrvatski geografski glasnik, vol. 76, no. 1, 41-59. doi: 10.21861/HGG.2014.76.01.03

Cvitanović M, Fuerst-Bjeliš B (2018) Marginalization Between Border and Metropolis: Drivers of Socio-Spatial Change in Postsocialist Croatia. In: Pelc S, Koderman M (eds) Nature, Tourism and Ethnicity as Drivers of (De)Marginalization, Insights to Marginality from Perspective of Sustainability and Development, Springer International Publishing AG, Cham, Switzerland, p 313-327. doi: 10.1007/978-3-319-59002-8_21

CLC 2006 Technical Guidelines. EEA Technical report, European Environment Agency, No.17, 2007

Corporate Finance Institute (2020) Regression Analysis. In: https://corporatefinanceinstitute.com/resources/knowledge/finance/regression-analysis/. Accessed 1 0ct 2020 
Dumbović Bilušić B (2015) Krajolik kao kulturno naslijeđe: metode prepoznavanja, vrjednovanja i zaštite kulturnih krajolika Hrvatske. Ministarstvo kulture Republike Hrvatske, Uprava za zaštitu kulturne baštine, Zagreb

Durbešić A (2012) Promjene pejzaža južne padine Svilaje - GIS pristup. Doktorski rad, Sveučilište u Zagrebu, Prirodoslovnomatematički fakultet, Geografski odsjek, Zagreb

Durbešić A, Fuerst-Bjeliš B (2016) Tipovi i trendovi promjene pejzaža planine Svilaje - Ogorje. Ekonomska i ekohistorija: časopis za gospodarsku povijest i povijest okoliša, vol. 12, no. 12, 208-220

Esbah H (2009) Analyzing Landscape Change Through Lanscape Structure Indices: Case of the City Aydin, Turkey. Journal of Applied Sciences, vol. 9, no. 15, 2744-2752. doi: 10.3923/jas.2009.2744.2752

ESRI (2019) How average nearest neighbor distance spatial statistics works. In: http://resources.esri.com/help/9.3/ArcGISDesktop/com/Gp_ToolRef/spatial _statistics_tools/how_average_nearest_neighbor_distance_spatial_statistics_works.htm. Accessed 5 Nov 2019

ESRI (2020) Buffer (Analysis). In: http://webhelp.esri.com/arcgisdesktop/9.3/index.cfm?TopicName=Buffer_(Analysis). Accessed 12 Sep 2020

Faivre S, Pahernik M (2007) Structural influences on the spatial distribution of dolines, Island of Brač, Croatia. Zeitschrift für Geomorphologie, vol. 51, no. 4, 487-503. doi: 10.1127/0372-8854/2007/0051-0487

Fu BJ, Hu CX, Chen LD, Honnay 0, Gulinck H (2006) Evaluating change in agricultural landscape pattern between 1980 and 2000 in the Loess hilly region of Ansai County, China. Agriculture, Ecosystems and Environment, vol. 114, no. 1-2, 387-396. doi: 10.1016/j.agee.2005.11.012

Fuerst-Bjeliš B, Lozić S, Perica D (2000) Man and the environment in the central Velebit area - Baške Oštarije and surroundings. Acta geographica Croatica, vol. 35, no. 1, 111-130

Fuerst-Bjeliš B (2002) Grimani Cadastral Survey and the Mediterranean geographical Environment (Case Study in Dalmatia). In: Arias Roca V (eds), Proceedings: 19th International Conference on the History of Cartography, Madrid, Spain, 1-6 July, p 110

Fuerst-Bjeliš B, D'Alessio G, Diklić, 0 (2003) Mletački katastar 18. stoljeća i ekohistorijska evaluacija tromeđe. In: Roksandić D, Štefanec, N (eds) Proceedings, 3. Međunarodna Projektna konferencija: Triplex Confinium (1500-1800): ekohistorija, Zadar, 3-7 May 2000, p 65-86

Fuerst-Bjeliš B (2003) Reading the Venetian Cadastral Record: An Evidence for the Environment, Population and Cultural Landscape of the 18th century Dalmatia. Hrvatski geografski glasnik, vol. 65, no. 1, 47-62. doi: 10.21861/HG.2003.65.01.03

Fuerst-Bjeliš B, Lozić S, Cvitanović M, Durbešić A (2011) Promjene okoliša središnjeg dijela Dalmatinske zagore od 18. stoljeća. In: Matas M, Faričić J (eds) Proceedings, Zagora između stočarsko-ratarske tradicije te procesa litoralizacije i globalizacije, Zadar Dugopolje, 19-21 October 2010, p 117-129

Herlitzius L, Linke HJ, Lüsse S, Palomba L (2009) Development of cultural landscape in Germany - topical aspects of the region of Starkenburg in South Hessen. In: Henrik J (eds) Cultural landscape - across disciplines, Oficyna Wydawnicza BRANTA, Bydgoszcz and Kraków, p 173-206

Jogun T, Pavlek K, Belić T, Buhin S, Malešić N (2017) Promjene zemljišnog pokrova u sjevernoj Hrvatskoj od 1981. do 2011. godine. Hrvatski geografski glasnik, vol. 79, no. 1, 33-59. doi: 10.21861/HGG.2017.79.01.02

Jogun T, Lukić A, Gašparović M (2019) Simulation model of land cover changes in a post-socijalist peripheral rural area: PožegaSlavonia County, Croatia. Hrvatski geografski glasnik, vol. 81, no. 1, 31-59. doi: 10.21861/HGG.2019.81.01.02

Jovanić, M (2017) GIS analiza i razvojna tipologija krajolika Srednje Like. Doktorski rad, Sveučilište u Zagrebu, Prirodoslovnomatematički fakultet, Geografski odsjek, Zagreb

Lang S, Blaschke T (2010) Analiza krajolika pomoću GIS-a. ITD-Gaudeamus d.o.o., Požega.

Morić-Španić A, Fuerst-Bjeliš B (2017) The GIS model for the revitalisation of traditional island cultures: the island of Hvar, Croatia. In: Pina H, Martin F (eds) The Overarching Issues of the European Space: Society, Economy and Heritage in a Scenario Towards Greater Territorial Cohesion, Faculdade de Letras da Universidadedo Porto, Porto, p 374-392

Nupp TE, Swihart RK, (2000) Landscape-level correlates of small-mammal assemblages in forest fragments of farmland. Journal of Mammology, vol. 81, no. 2, 512-526. doi: 10.1644/1545-1542(2000)081<0512:LLCOSM>2.0.C0;2

Olahová J, Vojtek M, Boltižiar M (2013) Application of geoinformation technologies for the assessment of landscape structure using landscape-ecological indexes (case study of the Handlová landslide). Tájökológiai Lapok, vol. 11, no. 2, 351-366

Pahernik M (2000) Prostorni raspored i gustoća ponikava SZ dijela Velike Kapele - rezultati računalne analize susjedstva. Geoadria, vol. 5 , no. 1, 105-120. doi: 10.15291/geoadria.156

Pahernik M, Jovanić M (2014) Geomorphologic database in the function of the Central Lika landscape typology (Republic of Croatia). In: Markoski B et al. (eds) Proceedings, International Scientific Symposium: Hilly-mountain areas - problems and perspectives, Skopje, Republic of North Macedonia, 12-15 September 2013, p 97-105

Paudel S, Yuan F (2012) Assessing landscape changes and dynamics using patch analysis and GIS modeling. International Journal of Applied Earth Observation and Geoinformation, vol. 16, 66-76. doi: 10.1016/j.jag.2011.12.003

Pejnović D (1985) Srednja Lika: socijalnogeografska transformacija. Centar za kulturu - Muzej Like, Gospić

Pelcer Z, Martinović J (2003) Odnos tla i šumske zajednice. In: Bogunović M (eds) Tla Gorske Hrvatske, Ministarstvo zaštite okoliša i prostornog uređenja, Ministarstvo znanosti i tehnologije, Zagreb and Osijek, p 56-68

Rutledge D (2003) Landscape indices as measure of the effects of fragmentation: can pattern reflect process?. DOC Science Internal Series, vol. 98, 5-27

Túri Z (2010) Studying landscape pattern in Great Hungarian Plain model areas. In: Rahmanov 0 (eds) Antrophogenic aspects of landscape transformations 6, University of Silesia, Sosnowiec - Bedzin, p 109-115 